Review

\title{
Emerging Concepts of Hybrid Epithelial-to-Mesenchymal Transition in Cancer Progression
}

\author{
Dona Sinha ${ }^{1, *}$, Priyanka Saha ${ }^{1}$, Anurima Samanta ${ }^{1}$ and Anupam Bishayee ${ }^{2, *}$ (C) \\ 1 Department of Receptor Biology and Tumour Metastasis, Chittaranjan National Cancer Institute, \\ Kolkata 700 026, India; poojasaha.saha79@gmail.com (P.S.); anurimasamanta@gmail.com (A.S.) \\ 2 Lake Erie College of Osteopathic Medicine, Bradenton, FL 34211, USA \\ * Correspondence: dona.sinha@cnci.org.in or donasinha2012@gmail.com (D.S.); \\ abishayee@lecom.edu or abishayee@gmail.com (A.B.)
}

Received: 12 October 2020; Accepted: 11 November 2020; Published: 16 November 2020

\begin{abstract}
Epithelial mesenchymal transition (EMT) is a complex process through which epithelial (E) cells lose their adherens junctions, transform into mesenchymal (M) cells and attain motility, leading to metastasis at distant organs. Nowadays, the concept of EMT has shifted from a binary phase of interconversion of pure $\mathrm{E}$ to $\mathrm{M}$ cells and vice versa to a spectrum of $\mathrm{E} / \mathrm{M}$ transition states preferably coined as hybrid/partial/intermediate EMT. Hybrid EMT, being a plastic transient state, harbours cells which co-express both $\mathrm{E}$ and $\mathrm{M}$ markers and exhibit high tumourigenic properties, leading to stemness, metastasis, and therapy resistance. Several preclinical and clinical studies provided the evidence of co-existence of $\mathrm{E} / \mathrm{M}$ phenotypes. Regulators including transcription factors, epigenetic regulators and phenotypic stability factors (PSFs) help in maintaining the hybrid state. Computational and bioinformatics approaches may be excellent for identifying new factors or combinations of regulatory elements that govern the different EMT transition states. Therapeutic intervention against hybrid $\mathrm{E} / \mathrm{M}$ cells, though few, may evolve as a rational strategy against metastasis and drug resistance. This review has attempted to present the recent advancements on the concept and regulation of the process of hybrid EMT which generates hybrid E/M phenotypes, evidence of intermediate EMT in both preclinical and clinical setup, impact of partial EMT on promoting tumourigenesis, and future strategies which might be adapted to tackle this phenomenon.
\end{abstract}

Keywords: collective migration; epithelial/mesenchymal phenotype; phenotypic stability factor; hybrid/partial EMT; metastasis; stemness

\section{Introduction}

Epithelial mesenchymal transition (EMT), is a complicated cellular process in which epithelial (E) cells lose adherence through cellular junctions, get deprived of apico-basolateral polarity, gain migratory potential and are transformed to mesenchymal (M) phenotype. EMT has been frequently associated with embryonic development, wound healing and cancer progression. During embryonic development, embryonic cells undergo EMT in order to migrate to a distant site and subsequently follow the reverse process, M-to-E transition (MET), to differentiate into various cell types. Likewise, cancer cells reactivate the EMT program during delamination from a primary tumour, migrate to distant organs, and form secondary tumours [1]. EMT is accompanied with disruption of adherens junctions and tight junctions, resulting in the dissemination of E cells. EMT aggravates the expression of $\mathrm{M}$ marker proteins, promotes attachment to the extracellular matrix (ECM) and acquisition of spindle-shaped $\mathrm{M}$ phenotype, enhances the migratory potential of an individual cell by reorganizing actin fibres and 
invades through basement membranes, blood and lymphatic vessels. Subsequent to intravasation, the cells primed for EMT survive as circulating tumour cells (CTCs) and ultimately extravasate into distant organs [2]. The CTCs harbour both E and M traits and exhibit hybrid E/M phenotypes (Figure 1) which impart them with plasticity and a survival advantage in different microenvironments during metastasis [3]. After extravasation, tumour cells need to undergo MET for metastatic colonization and growth at secondary sites. EMT endows cancer cells with aggressive phenotypes, drug resistance, aids suppression of senescence, anoikis, immune surveillance and acquisition of cancer stem cell (CSC)-like characteristics [4]. Conventional EMT has been often defined by the cadherin (cad) switch which indicates depletion of the epithelial marker E-cadherin (E-cad) and the gain of the M marker neural (N)-cadherin ( $\mathrm{N}$-cad). Migration of fibroblast-like $\mathrm{M}$ cells is mediated by integrin regulated interaction between cells and ECM [5]. EMT is governed by a multitude of factors which include ECM components, hypoxia, exosomes, non-coding RNAs, and growth factors such as hepatocyte growth factor (HGF), fibroblast growth factor (FGF) and transforming growth factor- $\beta$ (TGF- $\beta$ ) [4]. The mobility of the tumour cells is greatly influenced by the tumour microenvironment (TME) and the proximity to blood vessels [6]. EMT is frequently coupled with poorly differentiated tumours arising from different tissues.

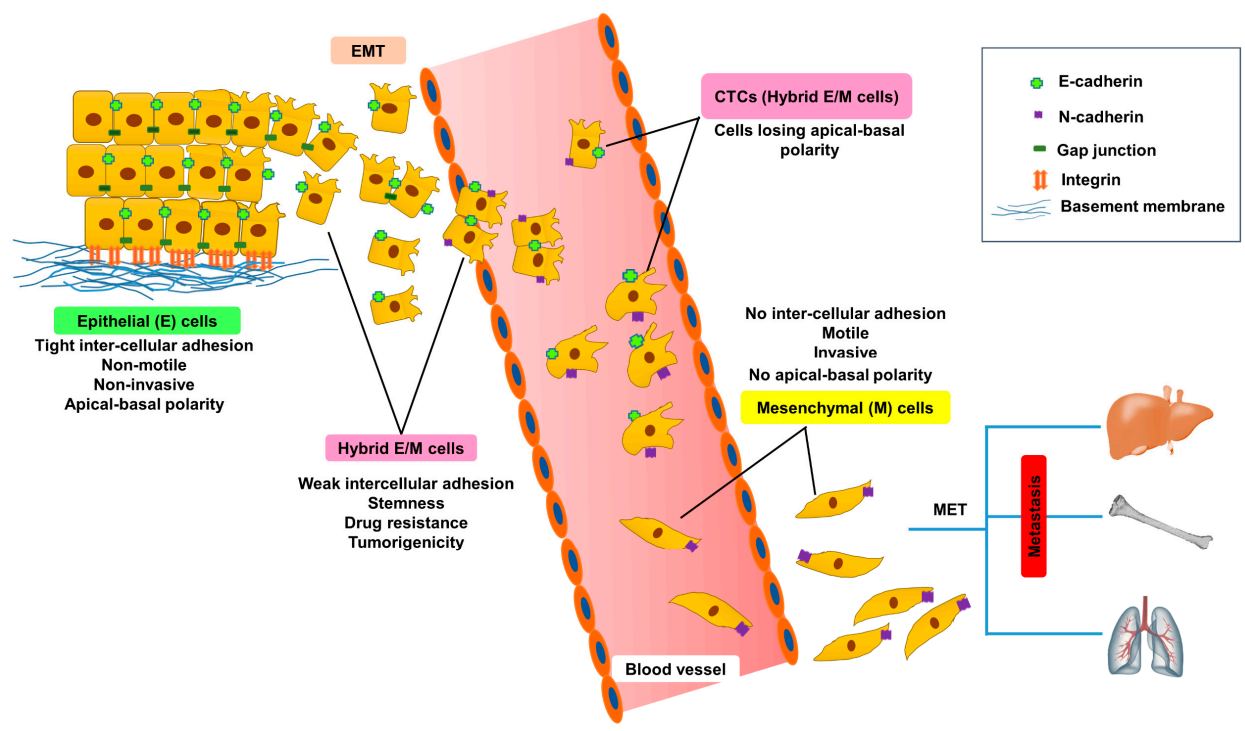

Figure 1. Hybrid E/M cells as a transition state of epithelial mesenchymal transition (EMT). E, M and $\mathrm{E} / \mathrm{M}$ specific markers and characteristics during different transition states. Loss of cellular adherens of E cells allow them to undergo EMT and are released into the blood circulations as circulating tumour cells (CTCs). CTCs were found to exhibit hybrid E/M phenotypes which can transform into $\mathrm{M}$ forms and induce metastasis through M-to-E transition (MET) at distant sites.

Recent studies indicated that instead of the binary process of EMT, occurrence of hybrid E/M phenotypes is a gradual transformation of $\mathrm{E}$ cells, through a number of intermediate stages to $\mathrm{M}$ form [7,8]. Partial/intermediate/hybrid EMT enables cancer cells to undergo migration and ECM attachment by virtue of their co-existing $\mathrm{E}$ and $\mathrm{M}$ characters, respectively, leading to stemness and tumour progression. There are some excellent reviews on specified aspects, such as CTCs [3]; role of EMT or partial EMT on cancer pathogenesis [9], metastasis [10], stemness, immune profile [11], and therapy resistance [12]. However, in this review, we have attempted to provide a complete knowledge oriented with the recent advancements on the concept and regulation of the process of hybrid EMT which generates hybrid E/M phenotypes, evidences of intermediate EMT in both preclinical and clinical setup, impact of partial EMT on promoting tumourigenesis and future strategies which might be adapted to tackle this phenomenon. Availability of the wide spectrum of partial EMT information on a single platform might be beneficial for both basic and clinical researchers. 


\section{Hybrid E/M and Their Plasticity}

Hybrid E/M phenotypes exhibit loss of apical-basal polarity, better motility while conserving adhesive property with neighboring cells and acquire $M$ features [6]. The plasticity of the tumour cells undergoing EMT vary according to their stage. The early hybrid E/M subpopulation shows inclination towards a hybrid E/M phenotype, the M subpopulation towards an $\mathrm{M}$ phenotype without spontaneous reversal towards an E phenotype and the hybrid E/M cells exhibit maximum plasticity as they are potent enough to give rise to both E and M phenotypes [13]. EMT or MET are not "all-or-none" processes; rather, cells can achieve one or more partial E/M states that may be more plastic in comparison with fully $\mathrm{E}$ or $\mathrm{M}$ cells [14]. In other words, the process of partial EMT is a dynamic transition of cells from the $\mathrm{E}$ to $\mathrm{M}$ phase. The intermediate $\mathrm{E} / \mathrm{M}$ stages exhibiting different levels of $\mathrm{E}$ and $\mathrm{M}$ markers, transcriptional, and epigenetic characteristics are specially localized at the invading edge of the tumour [6]. E-cad is depleted at the invading edge of the tumour but rich at the centre of the tumour [4]. Migration of multicellular clusters is exhibited by leading cells with hybrid E/M phenotypes (elevated $\mathrm{M}$ characteristics and actin-induced mobility) compared to central cells with $\mathrm{E}$ phenotypes (intact polarity and intercellular junctions and migration due to the leader cell mediated traction forces). In case of single-cell migration a full E/M phenotype is a prerequisite which signifies reduction of adhesive property, apicobasal polarity and promotion of individual cell motility [15]. Hybrid EMT is a multi-faceted process that involves alterations in genomic, epigenomic, morphology, metabolism, proliferative index, immune evasion, and tumour-initiation potential. The hybrid E/M phenotypes may vary both in position of occupancy and regulatory mechanisms [16]. A recent study reported that experimental knockout of zinc finger E-box binding homeobox 1 (ZEB1) gene along with induced expression of either zinc finger protein SNAI1, Slug, or Twist or TGF- $\beta 1$ exposure may convert E cells to hybrid $\mathrm{E} / \mathrm{M}$ cells which may be unable to progress into the $\mathrm{M}$ state. A stable hybrid $\mathrm{E} / \mathrm{M}$ state cell population was generated which exhibited high tumourigenicity and lacked plasticity in basal breast cancer cells [17]. Partial EMT poses greater metastatic risk than complete EMT [4] and the combined expression of $\mathrm{E}$ and $\mathrm{M}$ markers by the hybrid $\mathrm{E} / \mathrm{M}$ cells confer poor clinical prognosis in cancer [6].

\section{Markers of Hybrid EMT}

Hybrid EMT is generally marked by the co-expression of E and M proteins. Mammospheres produced from $\mathrm{E}$ and $\mathrm{M}$ sub-clones exhibited the co-expression of CD24 ${ }^{\mathrm{hi}} / \mathrm{CD} 44^{\mathrm{hi}}$ which confirmed the status of hybrid EMT. Other markers included placental-cadherin (P-cad), Slug, and integrin- $\beta$ 4 (ITGB4). A propagated hallmark of hybrid EMT is collective cell migration where P-cad and Slug are indicated to play pivotal roles [8]. However, hybrid E/M cell populations may not always co-express $\mathrm{E}$ and $\mathrm{M}$ markers, instead bulk proteomic measurements may also indicate their intermediate nature [18]. Three specific E/M biomarker proteins, regulator of G-protein signaling 16, plasminogen activator inhibitor-2 or SerpinB2 and an integrin $\alpha 3$ are upregulated in partial EMT cells and are not expressed exclusively by $\mathrm{E}$ or $\mathrm{M}$ cells [4]. Hybrid E/M status was divided into early and late hybrid E/M states according to the expression patterns of the surface markers, such as CD106, CD61, and CD51 [13]. Differential expression of CD104/CD44 determined various E/M states: E (CD104+CD44 $\left.{ }^{\mathrm{lo}}\right)$, hybrid E/M $\left(\mathrm{CD} 104+\mathrm{CD} 44^{\mathrm{hi}}\right)$, and M (CD104-CD44 $\left.{ }^{\mathrm{hi}}\right)$ cells [17].

\section{Regulation of Hybrid EMT}

Hybrid EMT is governed by phenotypic stability factors (PSFs), transcription factors (TFs), adherens junction proteins, namely E-cad and N-cad, epigenetic regulators, post-translational modifications and TME. Epigenetic regulators (methylation, acetylation, and non-coding RNAs) and post-translational modifications (phosphorylation, ubiquitination, and sumoylation) regulate the expression of various TFs, including SNAI1, Twist1, ZEB1, and ZEB2, which in turn augment EMT and subsequent metastasis. The following section will describe the plethora of varied mechanisms by which hybrid EMT is controlled. Several regulators of hybrid EMT are listed in Table 1. 
Table 1. Regulators of hybrid/partial EMT in various cancer models.

\begin{tabular}{|c|c|c|c|c|}
\hline Model & Regulators of Partial EMT & Effect & Mechanisms & Ref. \\
\hline Human bladder cancer (RT4), NSCLC (H1975) cells & NRF2 & Stabilize hybrid EMT & $\uparrow E-c a d, \uparrow Z E B 1$ & [19] \\
\hline Human clear cell RCC (SN12C and ACHN) cells & WT1 & \multirow[b]{2}{*}{ Hybrid EMT, tumourigenicity } & $\uparrow$ SNAI1, $\uparrow$ E-cad & [20] \\
\hline MDCK cells & YBX1 & & $\begin{array}{c}\uparrow \text { SNAI1, } \uparrow \text { Twist, } \uparrow \text { ADAM9, } \uparrow \text { ADAM17, } \uparrow \text { TGF- } \beta 1, \\
\uparrow C S F-1, \uparrow N G F, \uparrow \text { VGF, } \uparrow \text { SERPIN E1, }\end{array}$ & [21] \\
\hline Human breast (MCF10A) cells & PRRX2 & $\begin{array}{l}\text { Hybrid EMT, migration, invasion, } \\
\text { tumourigenesis, poor survival, } \\
\text { aggressiveness }\end{array}$ & 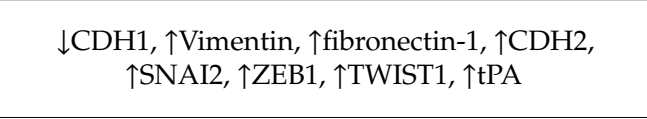 & [22] \\
\hline Human NSCLC (A549, H23) cells & miR-151a & $\begin{array}{l}\text { Partial EMT, proliferation, } \\
\text { migration }\end{array}$ & $\downarrow$ E-cad, $\uparrow$ fibronectin, $\uparrow$ Slug & [23] \\
\hline Human HNSCC (Cal27) cell & MYOSLID & Partial EMT, metastasis & $\uparrow$ Slug, $\uparrow$ PDPN, $\uparrow$ LAMB3 & [24] \\
\hline Human HCC (SNU-449) cells & HOTAIR & Hybrid EMT, migratory phenotype & $\begin{array}{c}\downarrow \text { F-actin stress fibrils, } \uparrow \beta \text {-catenin, } \uparrow \text { E-cad, } \\
\downarrow \text { Vimentin, } \downarrow \text { c-Met }\end{array}$ & [25] \\
\hline Human colorectal cancer (Caco-2) cells & NEO1 & \multirow{2}{*}{ Partial EMT, motility, metastasis } & $\begin{array}{c}\downarrow \text { F-Actin stress-fibres, } \downarrow \text { zonula adherens, } \uparrow \text { MMP1, } \\
\uparrow \text { fibronectin- } 1, \uparrow \text { ITGB1 }\end{array}$ & [26] \\
\hline HCCs from patients & DEPTOR & & $\begin{array}{c}\uparrow S N A I 1, \uparrow T G F-\beta 1 \text {-smad3/smad4 signaling, } \\
\downarrow \text { mTOR }\end{array}$ & [27] \\
\hline Human HCC (HepG2) cells & Endosulfan & Hybrid EMT, anoikis resistance & $\uparrow$ SNAI1, $\uparrow$ Slug, $\uparrow$ XIAP mRNA, $\uparrow$ fibronectin, & [28] \\
\hline $\begin{array}{l}\text { Human cervix (SiHa), pharynx (FaDu), } \\
\text { colorectal (HCT-116 and HT-29) cancer cells }\end{array}$ & TGF- $\beta 2$ & \multirow{4}{*}{ Hybrid EMT } & 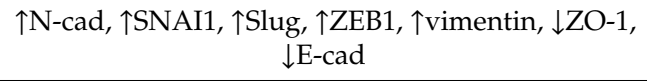 & [29] \\
\hline $\begin{array}{l}\text { Human inflammatory breast cancer (IBC) } \\
\text { (SUM149 and SUM190) cells }\end{array}$ & CSF-1 & & $\begin{array}{c}\downarrow \mathrm{E} \text {-cad, } \uparrow \text { vimentin, } \downarrow \text { Krt18, } \downarrow \text { CLDN1, } \uparrow \text { Twist1 } \\
\uparrow \text { SNAI1, } \downarrow \text { plakoglobin }\end{array}$ & [30] \\
\hline RCC from TSC patients & mTORC1 and mTORC2 & & E-cad+, vimentin+ & [31] \\
\hline CTCs of CRPC patients & FOXC2 & & E-cad+, N-cad+ & [32] \\
\hline Human HCC (Huh7) cells & Slug & $\begin{array}{l}\text { Partial EMT, enhanced motility, } \\
\text { chemo-resistance }\end{array}$ & $\uparrow$ fibronectin- 1 , $\uparrow$ Collagen type II alpha $1, \uparrow F G G$ & [33] \\
\hline
\end{tabular}

Abbreviations: ADAM, A disintegrin and metalloproteinases; CLDN1, claudin-1; CRPC, castration-resistant prostate cancer; CSF-1, colony stimulating factor 1; DEPTOR, DEP domain-containing mTOR-interacting protein; FGG, fibrinogen gamma chain; FOXC2- Forkhead box protein C2; HCC, hepatocellular carcinoma; HNSCC, head and neck squamous cell carcinoma; HOTAIR, HOX Transcript Antisense Intergenic RNA; IBC, inflammatory breast cancer; Krt, Keratin; LAMB3, laminin subunit beta 3; MDCK, Madin-Darby canine kidney cell; MMP, matrix metalloproteinase; mTOR, mammalian target of rapamycin; MYOSLID, myocardin-induced smooth muscle lncRNA, inducer of differentiation; NEO1, neogenin1; NGF, nerve growth factor; NRF2, nuclear factor erythroid 2-related factor 2; NSCLC, non-small cell lung carcinoma; PDPN, podoplanins; PRRX2, paired-related homeobox 2 transcription factor; RCC, renal cell carcinoma; tPA, tissue-type plasminogen activator; TSC, Tuberous sclerosis; WT1, Wilm's tumour transcription factor; XIAP, X-linked inhibitor of apoptosis protein; YBX1, Y box binding protein 1 . 


\subsection{PSFs Involved in the Maintenance of Hybrid E/M Phenotypes}

Several researchers have stated hybrid EMT as a transient state but several factors were found to stabilize or maintain the hybrid state [34]. Cellular clusters expressing Jagged dominated Notch signaling exhibited plasticity with better stability of hybrid E/M phenotypes [35]. In various cancer cells, such as triple negative breast cancer (TNBC) cells SUM159-PT and MDA-MB-231 and 4T1 cells, metabolic preprogramming permitted the malignant cells to perform both glycolysis and oxidative phosphorylation in order to maintain hybrid E/M status against an unfriendly microenvironment [36]. Stochastic simulations have deduced that grainyhead-like transcription factor 2(GRLH2), ovo-like zinc finger (OVOL), $\triangle \mathrm{Np} 63 \alpha$, microRNA (miR) 145/OCT4 play crucial role as PSFs in perpetuation of hybrid E/M phenotypes [37]. Nuclear factor erythroid 2-related factor 2 (Nrf2) has been deciphered as another important PSF for hybrid E/M form, whose constitutive expression upregulated both E-cad and ZEB1 in non-small cell lung carcinoma (NSCLC) and bladder cancer cells [19]. Feedback loops involving E splicing regulatory protein 1, hyaluronic acid synthase 2 and CD44 sustain elevated levels of ZEB1 and ascertain the stability of hybrid E/M phenotypes [38]. Numb, an inhibitor of Notch intercellular signaling, modulate Notch-driven EMT by inhibiting the H1975 lung cancer cells to undergo complete EMT and act as a PSF for maintaining stable hybrid E/M status [39].

\subsection{TFs Involved with Regulation of Different Stages of EMT}

Tumour cells in particular exhibit downregulation of E specific markers, such as the cad1 epithelial cell adhesion molecule (EpCAM), in the early stage of EMT and conserved expression of keratin (Krt) markers-Krt14, Krt5, or Krt8-in hybrid E/M cells which are completely depleted in the late stages of EMT [13]. Transcriptional repression of E-cad (hallmark of malignant tumours) is mediated by EMT-TFs, including ZEB1 and ZEB2, the Snai1 family (Snail, Slug, and Smuc) and basic helix-loop helix factors (Twist and E12/E47) [40]. ZEB1 and ZEB2 play a pivotal role in the positive regulation of EMT phenotypes and aggressiveness of cancer cells [41].

Different transition stages of EMT are associated with E and M specific TFs. Early hybrid EMT stages were initiated with the expression of ZEB1, transformation-related protein 63, Twist 1/2, and LIM/homeobox protein 2 while Smad2 promoted the latter stages of EMT [6]. M markers, including TFs, cad2, vimentin, SNAI1, Twist1/2, and ZEB1/2, were robustly expressed in early hybrid states and were conserved throughout $M$ stages. The late stages of EMT were marked with the prominent expression of cad11, platelet-derived growth factor receptor (PDGFR) A, PDGFRB, fibroblast activation protein, lysyl oxidase like-1, collagen 24A1, matrix metalloproteinase 19 (MMP19), or paired-related homeobox (PRRX)1. EMT is restrained and MET is induced by the OVOL2-mediated downregulation of ZEB1 [42]. The deletion of Twist1 or Snai1 alone was not sufficient to suppress EMT, while the deletion of ZEB1 had a greater impact on the tumour phenotype and metastasis [43]. Transcriptional activation of Snai1 by Wilms' tumour transcription factor (WT1) prevented repression of E-cad and conferred the hybrid E/M state in renal cancer [20]. Administration of Src kinase inhibitors in ovarian carcinoma cells with hybrid E/M phenotypes, caused regain of E-cad, suppressed Snai1 and Snai2 levels, while ZEB1, ZEB2, and Twist1 levels remained unaltered and contributed towards stabilization of hybrid E/M phenotypes [44]. WT1 evoked the hybrid E/M state in RCC by coherently upregulating SNAI1 and maintaining E-cad expression [20]. Sustained expression of TF, $\Delta N p 63 \alpha$ or suppressing the TGF- $\beta / S$ mad2 pathway increased the transition towards the early hybrid state than full EMT [13]. In normal Madin-Darby canine kidney (MDCK) cells, YBX1 overexpression induced partial EMT, by increasing several EMT TFs that can regulate tumour angiogenesis and anchorage-independent growth [21]. TGF- $\beta$ induced PRR homeobox 2 transcription factor upregulation in human breast cells, enhanced migration, and tumourigenesis [22]. 


\subsection{Epigenetic Regulators of Hybrid EMT-TFs}

Epigenetic regulation of hybrid EMT may be mediated by methylation, acetylation and non-coding RNAs. Chromatin modification by histone deacetylases and/or DNA methyl transferases (DNMTs) facilitate plasticity, aid transformation into hybrid E/M phenotypes, cause transcriptional repression of E genes, stabilise heterochromatin modification and facilitate the recruitment of DNMTs. In partial EMT, the repressed promoters have enriched tri-methylation at the 27th lysine residue of the histone $\mathrm{H} 3$ protein (H3K27me3) and impoverished tri-methylation at the 4th lysine residue of the histone $\mathrm{H} 3$ (H3K4me3). On the contrary, the activated promoters feature elevated levels of H3K4me3 and acetylation at the 27th lysine residue of the histone $\mathrm{H} 3$ protein $(\mathrm{H} 3 \mathrm{~K} 27 \mathrm{ac})$. Repressed enhancer regions also harbour mono-methylation at the 4th lysine residue of the histone $\mathrm{H} 3$ protein (H3K4me1) with absence/presence of H3K27me3, whereas activated enhancers are marked by H3K4me1 with pronounced H3K27ac [8] GRHL2 was observed to be associated with the epigenetic control of hybrid EMT [45]. The high-mobility group AT-hook 2 was also reported to govern the E-M plasticity and aggravation of intermediate EMT and M state [46]. TF $\triangle \mathrm{Np} 63 \alpha$ was associated with upregulation of Slug and Axl (member of the TYRO3-AXL-MER family of receptor tyrosine kinases), downregulation of ZEB1/2 by miR-205 and propulsion towards hybrid EMT in breast cancer [47]. A double negative feedback loop between the miR200 family and ZEB1 was proposed to regulate the E/M transition states [48]. A recently reported model known as the "ceRNA theory" and the nonsense-mediated mRNA decay pathway may be involved in EMT induction through multiple gene-expression networks, including EMT-TFs, in cancer cells [49]. An oncomiR, miR-151a, induced partial EMT and migration in NSCLC cells [23]. The upregulation of long noncoding RNA (lncRNA) myocardin-induced smooth muscle lncRNA, inducer of differentiation (MYOSLID) was associated with the modulation of partial EMT, leading to metastasis and poor prognosis in head and neck squamous cell carcinoma (HNSCC) [24]. Overexpression of lncRNA HOX Transcript Antisense Intergenic RNA (HOTAIR), maintained hybrid EMT phenotypes and induced migration in HCC cells [25].

\subsection{Post-Translation Modifications Control EMT-TFs and Adherens Junction Proteins}

Additionally, post-translational modifications, such as phosphorylation, ubiquitination and sumoylation, are largely known to regulate EMT-TFs [4]. The inhibition of glycogen synthase kinase $3 \beta$-mediated phosphorylation and subsequent ubiquitination of SNAI1 induced EMT. The subcellular localization of SNAI1 is regulated by kinases, such as pyruvate dehydrogenase kinase 1, large tumour suppressor kinase 2, and serine/threonine-protein kinase PAK 1, mediated phosphorylation. Apart from phosphorylation, SNAI1 is also controlled by lysine acetylation [8].

The adherens junction proteins, such as E-cad and N-cad, are dominant players of EMT. Post-translation modifications, including serine or threonine phosphorylation, tyrosine phosphorylation, GTPase binding, lipid binding, and proteolysis of the cadhesome proteins, mediate their interaction and activity in adherens junction dynamics [50]. Insulin-like growth factor-II induced the loss of E-cad by novel sumoylation in preclinical models of hepatitis B virus-induced hepatocellular carcinoma [51].

In short, the multiple regulatory networks control EMT-TFs, modify expressions of EMT marker proteins at the transcriptional, post-transcriptional, post-translational and epigenetic levels, and control EMT and aggressiveness in co-operation with additional factors secreted from cells and/or the cellular components in the TME.

\subsection{TME Influences Hybrid EMT}

TME influences both the transformation of the E-to-M form by EMT and the reversion of the M-to-E form by MET at distant metastatic sites [52]. During EMT, the components of the stromal tissue are altered by a marked increase of infiltrating monocytes, macrophages, blood and lymphatic vessels. TME components such as cancer-associated fibroblasts (CAFs), myofibroblasts and tumour-associated macrophages (TAMs), act in a concert and promote tumour development. Though the influence 
of TME in regulating the hybrid is not well elucidated, some reports have indicated that CAFs, TAMs and stromal components may govern intermediate stages of EMT [53]. Reactive stroma of TME, enriched with FGFs, HGF and tumour necrosis factor $\alpha$ act in association with TGF- $\beta$ to trigger EMT in cancer cells and facilitate collective migration at invasive front of the multicellular clusters [3]. CAFs inflict tumour proliferation, invasion and metastasis. Collective cancer cell migration always occurs within tracks (generated by protease/force mediated matrix remodelling) in the ECM behind the leading CAF [3]. Single cell migration is mediated by anterior CAFs which secrete membrane type 1 metalloprotease and create microtracks. These microtracks pave the way for single cell migration followed by collective cell migration accompanied with large-scale degradation of lateral ECM interfaces [54]. Since cells exhibiting hybrid E/M characters localize at the junction between tumour hive and tumour stroma, a heterogeneous adherens junction which expressed E-cad on the cancer cell membrane and $\mathrm{N}$-cad on the CAF membrane was propagated to promote fibroblast-led collective cancer cell migration [55]. The activation of coagulation (fibrin/platelets network) surrounding tumour cells shields CTCs against natural killer (NK) surveillance by inducing TGF- $\beta$-mediated suppression of C-type, lectin-like, and type II transmembrane glycoprotein NKG2D or by expressing platelet MHC-class I molecules which camouflage CTCs from NK cells [3]. CTCs interact with neutrophil clusters through secretion of chemokines (granulocyte colony stimulating factor, chemokine ligand (CXCL) 1, CXCL8, or CXCL5) and varied adhesive receptors (vascular cell adhesion molecule 1, intercellular adhesion molecule, and $\beta 1$ integrin) which in turn have been related to poor prognosis in breast cancers [3].

\subsection{Exosomes in Regulation of Hybrid EMT}

Emerging evidence has shown that extracellular vesicles, such as exosomes, are also associated with EMT. Exosomes released from tumour cells contains EMT signature as evident from Ras-transformed MDCK (21D1) cell-derived exosomes. Exosomes may induce EMT on recipient cells upon their uptake [21]. 21D1 exosomes contained the transcription/splicing factor and RNA-binding protein nuclease-sensitive element-binding protein 1 (YBX1/YB-1) which induces partial EMT [21]. Slug-mediated partial EMT caused increased exosomal secretions of fibronectin1, collagen type II $\alpha 1$ and native FGG which acts as biomarkers for hybrid EMT in HCC cells [33]. The cells undergoing a partial EMT were also found to secrete cytokines and exosomes that enabled recruitment of macrophages and bone-marrow-derived $\mathrm{M}$ cells to sustain inflammation and promote fibrogenesis, respectively [56]. A proteomics study revealed that hypoxic tumour cells produced chemokines and immunomodulatory proteins, e.g., macrophage colony stimulating factor-1-rich exosomes that eluded host immunity and enhanced tumour progression. Thus, hypoxia and exosomes together enabled partial EMT and tumour aggressiveness [57]. Though exosomes carry several EMT signature molecules, more elaborate studies are needed to establish a significant regulatory relationship of exosomes with partial EMT.

\subsection{Mathematical Modeling as a Predictor of Hybrid EMT Regulation}

The computational models have predicted that EMT and MET may not be symmetric processes and cells in a clonal subpopulation may get interconverted in multiple forms $\mathrm{E}, \mathrm{M}$ or hybrid $\mathrm{E} / \mathrm{M}$ phenotypes [16]. Recent advancements have been made to explore the enhancer logic and gene regulatory networks (GRNs) that control the different EMT states. Tumour-specific active enhancers of $\mathrm{E}$ and $\mathrm{M}$ tumour cells are rich with TF activator protein 1, E26 transformation-specific, transcriptional enhanced associate domain, Runt-related transcription factor, and nuclear factor- $\mathrm{k}$-light-chain-enhancer of activated B cells (NF- $\mathrm{KB}$ ) binding sites, indicating that the similar cores of TFs activate chromatin remodeling during EMT $[13,58]$. Mathematical modeling has been advocated for prediction of the GRNs that augmented the E, M, and hybrid states. These models also predict the interaction of $\mathrm{E}$ and M TFs and miRs may form a mutually inhibitory loop which may either lead to an $\mathrm{E}$ or M phenotype depending on the domination of the specific TF/miR e.g., miR34/ snai1 or miR200/Zeb loops. The mutually inhibitory loop may be also promoted to a hybrid E/M phenotype in the absence 
of any strong inhibition/expression of the loop members. Mathematical modeling elicited NRF2, OVOL2, GRHL2, Numb and Notch-Jagged signaling as stabilizers of hybrid E/M and suppressors of complete EMT [6]. TFs, OVOL2 or GRHL2, aggravated the hybrid EMT state with high tumourigenic potential and poor patient prognosis [6]. Inhibition of OVOL2 or GRHL2 has been observed to retard collective cell migration [59]. The coupling of OVOL with miR-200/ZEB/LIN28/let-7 network was mathematically deduced to control the stemness of the hybrid E/M phenotype [60]. In the presence of TGF- $\beta$, Notch1 has been observed to inhibit Notch3 and activate ZEB1, which in turn has been associated with the promotion of hybrid EMT [61]. Numerical simulations have provided insight that the noise and the time of delay act oppositely on the expression of ZEB, which in turn determines the transition of the E/M spectrum [62]. Bioinformatic strategy observed that the nuclear factor of activated T-cells and specificity protein 1 concerted as master regulators for facilitating a hybrid E/M phenotype in non-transformed mammary gland cells and colorectal cancer cells [6]. A recent transcriptomics based scoring metrics was proposed to be effective in differentiating pure hybrid E/M population from the cluster of $\mathrm{E}$ and $\mathrm{M}$ cells [63]. Altogether, the computational approaches provide systematic tools to speculate the regulatory factors of the $\mathrm{E}$ and $\mathrm{M}$ transformation spectrum which further need experimental validations.

\subsection{Miscellaneous Regulators}

NEO1 receptor of the deleted in colorectal carcinoma/Frazzled/UNC-40 family stabilizes E adherens junctions, while loss of NEO1 leads to the disruption of zonula adherens. Loss of NEO1 may lead to metastasis by inducing partial EMT in human colorectal cancer cells by maintaining E connections and acquiring more migratory cellular morphology and changes in gene expressions [26]. DEPTOR protein was found to act as an inhibitor of mammalian target of rapamycin (mTOR). Overexpression of DEPTOR promotes proliferation and survival of cancer cells. DEPTOR induces a partial E-to-M transition and metastasis via autocrine TGF- $\beta 1$ signaling in HCC [27]. Endosulfan is an organochlorine pesticide that is mainly metabolised by cytochrome P450 (CYP) enzymes, CYP2B6 and CYP3A4, in human liver. Endosulfan was found to induce changes in the expression of epithelial characteristics, disrupted the anoikis process, modulated the cytoskeletal architecture and thus appeared to induce a partial EMT-like event that occurred without cell migration in HepG2 cells [22,28]. Autocrine TGF- $\beta 2$ signaling facilitated the formation of lipid droplets that promoted partial EMT and helped as energy stores during local invasiveness, anoikis resistance, and distant metastasis in different human cancers [29]. In inflammatory breast cancer (IBC) cells, the colony stimulating factor (CSF)-1/ receptor tyrosine kinase of CSF-1 (CSF-1R) axis has a functional role in hybrid E/M phenotype development and metastasis [30]. mTORC1 and mTORC2 were activated in renal cell carcinoma, and existence of hybrid E/M cells indicated partial EMT [31]. Forkhead box protein C2 expression was associated with co-expression of $\mathrm{E} / \mathrm{M}$ markers in castration resistant prostate cancer (CRPC)s [32]. Several PSFs and other regulators of hybrid EMT are schematically represented in Figure 2. 


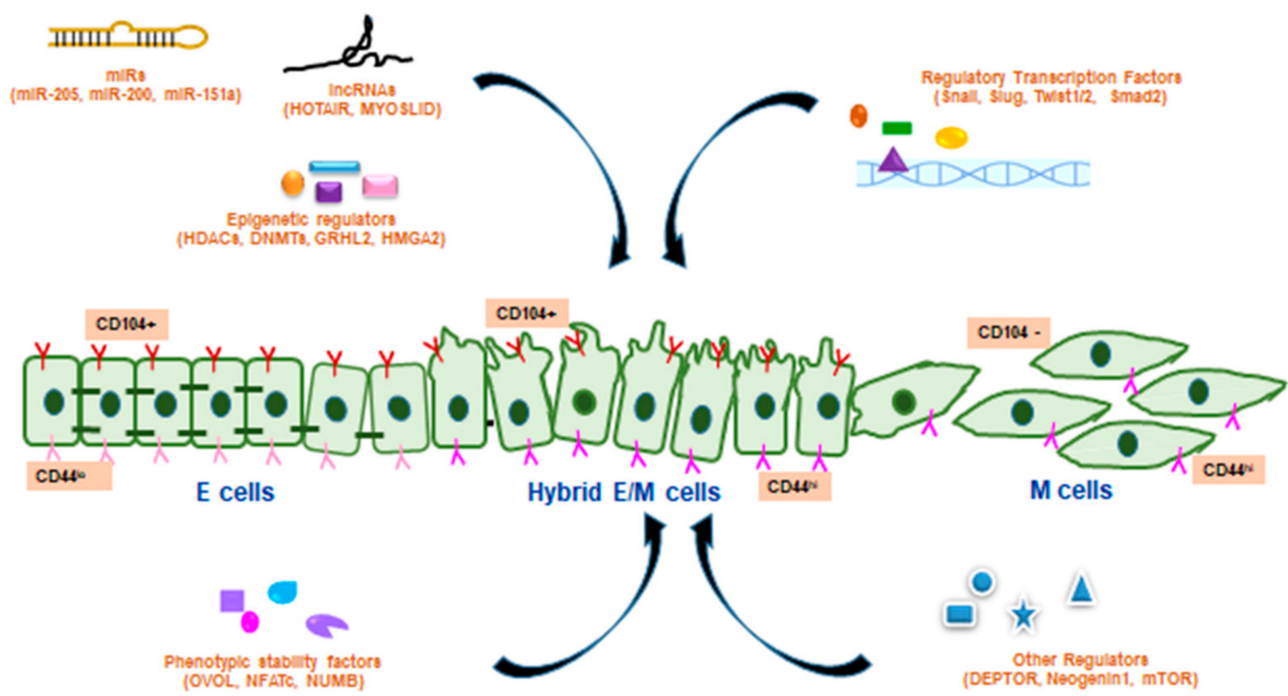

Figure 2. Regulation of hybrid EMT by various factors. The hybrid E/M transition state (CD104+CD44hi) between the $\mathrm{E}\left(\mathrm{CD} 104+\mathrm{CD} 44^{\mathrm{lo}}\right)$ and $\mathrm{M}\left(\mathrm{CD} 104-\mathrm{CD} 44^{\mathrm{hi}}\right)$ phenotypes are regulated by various factors including micro RNAs (miR), long non-coding RNAs (lncRNAs), other epigenetic regulators, regulatory TFs of hybrid EMT, phenotypic stability factors (PSFs) and other regulators of hybrid EMT.

\section{Preclinical and Clinical Evidence of Hybrid EMT}

Growing evidence of preclinical and clinical studies exhibited an emerging role of hybrid E/M phenotypes as an important factor of tumourigenesis. The hybrid EMT state of tumour cells remains in a different EMT spectrum than those tumour cells in the completed E/M phenotype [34]. The hybrid EMT state may regulate different factors of tumour progression including co-expression of E/M markers, stemness, tumourigenicity and metastasis along with changes in cellular shape and behavior [64].

\subsection{In Vitro Studies}

In IBC cells, CSF and CSF1R signaling network was observed to drive hybrid E/M phenotypes and aggravate metastasis [30]. Co-expression of $\mathrm{E} / \mathrm{M}$ markers along with stemness were evident with triple-negative IBC cells [65]. CD24+/CD44+ double positive human mammary epithelial (HMLER) cells co-expressed multiple E/M genes, exhibited stemness and enhanced aldehyde dehydrogenase1 (ALDH1) activity [66]. A hybrid E/M population of HMLER cells resulted into high tumourigenicity and stemness but lacked plasticity [17]. In the hTGF- $\beta 1$-induced EMT of human mammary MCF10A cells, a certain population of cells exhibited hybrid EMT [67]. E/M double positive hybrid lung adenocarcinoma cells exhibited aggravated migration as $\mathrm{M}$ feature and high aggregation property as an E characteristic [18]. Erlotinib-resistant NSCLC cells harboured a subpopulation of hybrid E/M cells, which showed a tendency for in vitro spheroid formation but did not exhibit increased cell migration or invasion in comparison to their erlotinib-sensitive parental cells [68]. PC-3/Mc cells, a subpopulation of prostate cancer PC-3 cells, were proposed to be hybrid E/M cells with higher tumour initiation potential and an active self-renewal program [69]. Primary tumour-derived prostate cancer cells also exhibited a hybrid phenotype along with stemness properties [70]. Human pancreatic cancer cells showed collective migration with hybrid EMT under experimental conditions [71].

\subsection{In Vivo Studies}

A serial xenotransplantation of unsorted rhabdomyosarcoma cells in non-obese diabetic/severe combined immunodeficiency (NOD/SCID) $\gamma$ (NSG) mice induced hybrid E/M phenotypes [72]. Hybrid EMT was detected in primary colorectal cancer cells and also in its patient-derived xenografts (PDXs) model [73]. In the ovarian cancer xenograft model, some subpopulation of cells were found to be in hybrid E/M multipotent phenotype [74]. Human pancreatic cancer stem cells, which exhibited 
co-expression of $\mathrm{E} / \mathrm{M}$ markers were able to induce tumour growth in the xenograft model [75]. In the LSL-KrasG12D; p53loxP/+; Pdx1-cre; LSL-Rosa26YFP/YFP (KPCY) mouse model of pancreatic ductal adenocarcinoma (PDAC), cell populations expressed partial EMT [76]. The crossing of the $\mathrm{Pb}-\mathrm{Cre}+/-; \mathrm{PtenL} / \mathrm{L} ; \mathrm{KrasG} 12 \mathrm{D} /+$ prostate cancer model with vimentin green fluorescence protein (GFP) reporter strain generated the Pb-Cre+/-;PtenL/L;KrasG12D/+;Vim-GFP (CPKV) mice model which exhibited E, E/M and $\mathrm{M}$ states [77]. Co-expressions of E/M markers were also evident in prostate cancer xenografts [78]. During the spontaneous EMT of primary skin tumours in the genetic mouse model of skin squamous cell carcinoma (SCC) with conditional KRasG12D expression and p53 deletion in hair follicles, some subpopulations of tumour exhibited hybrid EMT [13].

\subsection{Clinical Evidence of Partial EMT in Human Cancers}

Several pieces of clinical evidence, mostly with CTCs, showed the existence of hybrid E/M phenotypes during EMT. Partial EMT has been observed with CTCs of the human blood in NSCLC, prostate, breast, liver, colorectal, gastric, and nasopharyngeal cancers [6]. CTCs are regarded as biomarkers of cancer prognosis. In case of advanced cancers, CTCs frequently exhibit pronounced hybrid E/M phenotypes and collective migration of cells [8]. Partial EMT features are also evidenced from $\mathrm{M}$ gene expression of the stromal cells around the primary tumours [79] of breast, lung and prostate [8]. In HNSCC, the leading edge of primary tumours elicits partial EMT features and helps in determining nodal metastasis. Single cell transcriptomic analysis from a primary tumour of HNSCC patients exhibited hybrid EMT [80]. In colorectal cancer tumour buds, small groups of tumour cells in the stroma are thought to be representative of partial EMT and poor prognosis [81]. Primary prostate cancer cells exhibited a hybrid E/M phenotype from prostate cancer patients [82]. Co-expressions of E/M markers were also evident from metastatic tumour sites of prostate cancer patients [78]. Hybrid expressions of E/M phenotypes were identified in CTC from metastatic NSCLC patients [83], ovarian cancer patients [84] and patients with metastatic CRPC [85]. The expression of hybrid EMT markers was observed in esophageal squamous cell carcinoma (ESCC) samples from primary tumours with paired metastatic lymph nodes (MLNs) [86]. In early breast cancer patients, EpCAM+CTCs express both $\mathrm{M}$ and stemness-related genes; the overexpression of these markers may be associated with worse prognosis [87]. Hybrid expressions of E/M phenotypes were identified in CTC from metastatic breast cancer patients [85]. Co-expression of E/M markers both in the primary breast cancer site and metastatic lymph nodes exhibited the worst survival rates among the patients [88]. Evidence showed tumour buds undergoing partial EMT in colorectal cancer patients [89]. Primary human high-grade serous ovarian cancer (HGSOC) tumour exhibited co-expression of E/M markers [90]. Primary human adenocarcinomas and SCC showed evidence of co-expression of E/M markers along with migratory properties [91].

Emerging evidence of hybrid E/M phenotypes promoting tumourigenic properties in preclinical and clinical models is shown in Table 2. 
Table 2. Evidence of hybrid E/M phenotypes in various in vitro, in vivo models and clinical studies.

\begin{tabular}{|c|c|c|c|}
\hline Model & Effect & Mechanism & Ref. \\
\hline \multicolumn{4}{|c|}{ In Vitro Studies } \\
\hline HMLER cells & Hybrid EMT, stemness & $\begin{array}{c}\downarrow \text { Krt 5, } \downarrow \text { Krt } 8, \downarrow \text { pan-cytokeratin, } \downarrow \text { E-cad, } \\
\uparrow \text { vimentin, } \uparrow Z \text { ZEB1, } \uparrow \text { SNAI1 }\end{array}$ & [17] \\
\hline $\begin{array}{l}\text { Human lung adenocarcinoma (DFCI032, H1650, H1693, } \\
\text { HCC827) cells }\end{array}$ & Hybrid EMT, invasion, migration & E-cad+, Vimentin+, $\uparrow Z E B 1, \uparrow S N A I 2, \uparrow m i R-34 a$ & [18] \\
\hline Human lung adenocarcinoma (H1975) cells & Cell migration, hybrid EMT & $\downarrow$ GRHL2, $\downarrow$ OVOL2, $\downarrow$ E-cad (CDH1), $\uparrow$ ZEB1 & [59] \\
\hline IBC (SUM149, Mary-X and FC-IBC02) cells & $\begin{array}{l}\text { Co-expression of E/M phenotype, } \\
\text { Stemness }\end{array}$ & CD44+, $\uparrow$ TWIST1, $\uparrow$ E-cad, $\uparrow D S C 2, \uparrow$ Vimentin & [65] \\
\hline HMLER cells & $\begin{array}{l}\text { Hybrid EMT, plasticity, stemness, } \\
\text { mammosphere formation }\end{array}$ & CD24+/CD44+, $\uparrow \mathrm{ALDH} 1$ & [66] \\
\hline Human mammary epithelial (MCF 10A) cells & Hybrid EMT & $\begin{array}{c}\text { E-cad }^{\text {medium }} \\
\text {, }_{\text {ZEB1mentin }}^{\text {medium }} \\
\text { medium } \\
\text {, SNAI1 }\end{array}$ & [67] \\
\hline Human erlotinib-resistant NSCLC (HCC827) cells & $\begin{array}{l}\text { Hybrid EMT, cell migration, spheroid } \\
\text { formation }\end{array}$ & Cad-1+, Vimentin+, ZEB1 ${ }^{\text {hi }}$ & [68] \\
\hline Human prostate cancer (PC-3/Mc) cells & Hybrid EMT, stemness & $\mathrm{CD} 24+, \mathrm{CD} 44+$ & [69] \\
\hline $\begin{array}{l}\text { Primary tumour- derived human prostate cancer } \\
\text { (OPCT-1) cells }\end{array}$ & \multirow{3}{*}{ Co-expression of E/M phenotype } & $\begin{array}{c}\text { E-cad+, vimentin+, cytokeratin+, fibronectin+, } \\
\text { N-cad+, SNAI1+, Slug }+\end{array}$ & {$[70]$} \\
\hline $\begin{array}{l}\text { Human pancreatic cancer } \\
\text { (PANC1 and MIAPACA2) cells }\end{array}$ & & $\downarrow$ E-Cad, $\uparrow Z E B 1, \uparrow v i m e n t i n$ & [71] \\
\hline $\begin{array}{l}\text { Human NSCLC (A549, H460), primary NSCLC } \\
\text { (LT73) cells }\end{array}$ & & $\uparrow \mathrm{CDH} 1, \uparrow \mathrm{SNAI} 2$ & [92] \\
\hline \multicolumn{4}{|c|}{ In Vivo Studies } \\
\hline Genetic SCC mouse model & Hybrid EMT & Krt 14+, vimentin+ & [13] \\
\hline Primary rhabdomyosarcoma NSTS- 11 cells in NSG mice & Hybrid EMT, stemness & $\begin{array}{c}\uparrow(\mathrm{ZEB} 1, \mathrm{MME}, \mathrm{LAMC} 2, \text { or COL3A1), } \downarrow(\mathrm{N}-\mathrm{cad}, \\
\text { SNAI1, FGF2, AOX1, or ANKRD1), } \\
\uparrow(\mathrm{KRT} 5, \mathrm{LAMA3} \text {, or ANK3), } \downarrow(\mathrm{E}-\mathrm{cad}, \mathrm{P}-\mathrm{cad}, \\
\text { KRT14, KRT17, or KRT18) }\end{array}$ & [72] \\
\hline
\end{tabular}


Table 2. Cont

\begin{tabular}{|c|c|c|c|}
\hline Model & Effect & Mechanism & Ref. \\
\hline Primary human colorectal cancer PDXs in NOG mice & $\begin{array}{l}\text { Hybrid EMT, } \\
\text { metastasis }\end{array}$ & E-cad,+ ZEB1+ & [73] \\
\hline $\begin{array}{c}\text { Primary human ovarian cancer ocv316-X tumour } \\
\text { xenograft in SCID-beige mice }\end{array}$ & \multirow{4}{*}{ Co-expression of E/M markers } & E-cad+, Vimentin+ & [74] \\
\hline KPCY mouse model of PDAC & & $\beta$-catenin,+ Claudin-7+, EpCAM+, E-cad + & [76] \\
\hline Primary prostate cancer CPKV mice model & & EpCAM+, Vimentin+ & [77] \\
\hline Prostate cancer DU145 subline in mouse xenografts & & E-cad+, ZEB1+ & [78] \\
\hline \multicolumn{4}{|c|}{ Clinical Studies } \\
\hline Primary CRC tumour & Hybrid EMT & E-cad+, ZEB1+ & [73] \\
\hline Metastatic tumour sites in prostate cancers patients & Co-expression of E/M markers & E-cad,+ ZEB1+ & [78] \\
\hline Primary HNSCC tumours & $\begin{array}{l}\text { Hybrid EMT, } \\
\text { metastasis }\end{array}$ & $\uparrow$ Vimentin, $\uparrow$ integrin $\alpha-5$, $\uparrow$ laminins, $\uparrow$ MMPs & [93] \\
\hline Primary prostate cancer cells & \multirow{3}{*}{ Co-expression of E/M markers } & E-cad+, Vimentin+, Fibronectin+ & [82] \\
\hline CTC from patients with metastatic NSCLC & & Vimentin+, Krt+ & [83] \\
\hline CTCs from ovarian cancer patients & & $\begin{array}{c}\text { EpCAM+, CK5/7+, Muc-1+, N-cad+, Vimentin+, } \\
\text { Snai+ }\end{array}$ & [84] \\
\hline CTCs from patients with metastatic CRPC & $\begin{array}{l}\text { Hybrid EMT, } \\
\text { stemness }\end{array}$ & $\begin{array}{c}\text { EpCAM+, Cytokeratins+, E-cad+, } \\
\text { Vimentin+, N-cad+, O-cad+, CD133+ }\end{array}$ & [85] \\
\hline CTCs from women with metastatic BT & \multirow{2}{*}{ Hybrid EMT } & Cytokeratins+, Vimentin+, N-cad+ & [85] \\
\hline ESCC PT or MLN specimen from ESCC patients & & E-cad,$+ \mathrm{N}$-cad+, vimentin + & [86] \\
\hline CTC from early stage breast cancer patients & stemness & TWIST1+, CD44+, ALDH1+, EpCAM+ & [87] \\
\hline $\begin{array}{l}\text { Breast cancer samples from primary site and metastatic } \\
\text { lymph nodes of breast cancer patients }\end{array}$ & \multirow{4}{*}{ Co-expression of E/M markers } & E-cad+, vimentin+ & [88] \\
\hline Human primary colorectal cancer specimen & & Cytokeratin+, vimentin+ & [89] \\
\hline Primary HGSOC tumour & & E-cad+, vimentin+ & [90] \\
\hline Primary AC, SCC tumours & & Vimentin+/cytokeratin+, E-cad+/N-cad+ & [91] \\
\hline
\end{tabular}

Abbreviations: ANKRD1, ankyrin repeat domain-containing protein 1; AOX1, aldehyde oxidase 1; COL3A1, collagen Type III $\alpha 1$ Chain; FGF2, fibroblast growth factor; LAMC2,

laminin subunit $\gamma 2$; MME, membrane metallo-endopeptidase. 


\section{Impact of Partial EMT}

Cells harbouring intermediate EMT not only impart enhanced metastasis but also inflict cancer stemness and resistance to anoikis, chemotherapy and radiotherapy. The hybrid E/M cells are pleiotropic and aggressive in nature since they have characteristics of autocrine and paracrine signaling, cellular and extracellular attachments, and rapid proliferative property [16].

\subsection{Aggravated Metastasis}

Recent evidence suggests that hybrid EMT may be even more effective than a complete EMT, in spreading metastasis and therapy resistance. In comparison to the isolated expression of vimentin alone, the dual expression of $M$ marker vimentin and $E$ markers cytokeratins 8 and 18, promoted invasiveness, metastasis and poor prognosis in breast cancer [16]. Matrix detachment may upregulate 5'-AMP-activated protein kinase mediated Twist expression necessary for hybrid EMT which is frequently evidenced in CTCs [94]. EpCAM+/CD44+ CTCs isolated from breast cancer patients inflicted bone metastasis in immunodeficient NSG mice [95]. Hybrid EMT increased tumour heterogeneity and imparted advantage during metastasis and drug resistance in IBC [96]. Ovarian cancer has been also evidenced to metastasize by collective cellular migration to form secondary lesions [97]. Partial EMT, by virtue of its tumour heterogeneity, promotes macrometastases. Activation of complete EMT in hybrid PC-3/Mc prostate cancer cells increased their invasiveness, but retarded anchorage-independent growth, stemness and metastasis [98]. Partial EMT in head and neck cancer influenced nodal metastasis, lymphovascular invasion and extranodal extension [80]. Cad-6, a target of TGF- $\beta$ was found to inhibit autophagy and drive hybrid E/M-mediated aggressive metastasis in thyroid cancer [99].

\subsection{Cancer Stemness}

CSCs are characterized by enhanced tumourigenic capability and have the potential of self-renewal and differentiation into different types of tumour cells. CSCs attain hybrid E/M phenotypes with their existing E character and by concurrently gaining an $\mathrm{M}$ character that enhances their motility; thus, they act as leaders of metastasis [100]. EMT has been intertwined with cancer stemness and tumour propagating potential. The hybrid EMT state shows greater propensity to acquire CSC properties [64]. The hybrid E/M cells (CD44 ${ }^{\text {hi }} / \mathrm{CD} 24^{\text {hi }}$ ) exhibited greater capability of forming mammospheres and formed large tumours in nude mice than E $\left(\mathrm{CD} 44^{\mathrm{lo}} / \mathrm{CD} 24^{\mathrm{hi}}\right)$ or $\mathrm{M}\left(\mathrm{CD} 44^{\mathrm{hi}} / \mathrm{CD} 24^{\mathrm{lo}}\right)$ forms [101]. Highly metastatic TNBC cells have also been evidenced with ITGB4+ hybrid E/M cells with CSC property [102]. Activation of the Notch-Jagged pathway maintains clusters of CTCs and stemness in IBC [16]. Breast cancer cells harbouring partial EMT have been associated with the expression of ALDH1, and such cells are potent enough to give rise to both CSCs and differentiated cells [103]. In the CPKV mouse model of prostate cancer, hybrid E/M cells, enriched with Lin-/Sca1+/CD49f ${ }^{\text {hi }}$ stem/progenitor cells showed a propensity towards spheroid formation [77]. Hybrid E/M clone P4B6 obtained from OPCT-1 prostate cancer cells exhibited pronounced expression of stem cell markers, such as SOX2, CD44, and NANOG, which in turn caused faster and larger aided tumour formation [70]. In ovarian cancer, hybrid $\mathrm{E} / \mathrm{M}$ phenotypes induced greater stemness than fully $\mathrm{E}$ or fully $\mathrm{M}$ phenotypes [74]. It has been reported that, in NSCLC, TGF- $\beta 1$ promoted the expression of CD133+ in hybrid E/M cells (expressing both E-cad and SLUG) which in turn caused conversion of non-stem cells to CSCs [92].

\subsection{Therapy Resistance}

The impact of hybrid EMT in therapy resistance is yet to be deciphered, although several studies have indicated that intermediate stages of EMT are more vulnerable to chemo- and radio-resistance. NSCLC cells harbouring hybrid E/M characteristics were found to be resistant to epithelial growth factor receptor (EGFR) inhibitor, which in turn increased the ZEB1-mediated sphere formation property [68]. The resistance towards EGFR inhibitors by lung cancer cells has been attributed to cellular memory, 
especially exhibited by metastable cells [16]. Breast cancer patients with elevated levels of hybrid EMT markers, such as ITGB4 [102], GRHL2 [104] and $\Delta$ Np63 $\alpha$ [47], were resistant to chemotherapy and exhibited poor relapse-free survival. In ovarian cancer, miR-200c regulates the expression of class III $\beta$ tubulin and partial EMT, thereby contributing to chemotherapy resistance [16]. A subline of BxPC-3, pancreatic cancer cells with dual expression of ZEB1 and the E-cad characteristic of hybrid EMT exhibited gemcitabine resistance [105]. Colorectal cancer cells, with partial EMT co-expressed ZEB1, ZEB2, Twist and E-cad and elicited resistance against 5-fluorouracil [106].

\section{Conclusions}

Emerging evidence indicates that, instead of complete EMT, hybrid EMT plays a pivotal role in the promotion of cellular plasticity, collective migration, cancer stemness, drug resistance, and metastasis. Despite the recent advancements and in-depth knowledge of the TFs regulated EMT and MET mechanisms, some important areas are yet to be elucidated. The markers of hybrid EMT, specific regulatory molecules involved with the stabilization of the hybrid E/M phenotype and those related with the transition from the hybrid EMT to complete EMT or MET remain unsolved. Computational and bioinformatics approaches may be excellent for identifying new factors or combinations of regulatory elements that govern the different EMT transition states. The EMT scoring metric was shown to differentiate between pure hybrid $\mathrm{E} / \mathrm{M}$ cells from mixtures of $\mathrm{E} / \mathrm{M}$ subpopulations by utilizing computational method random circuit perturbation mediated gene expression data [11]. However, careful experimental designs are needed to validate these predictions. However, transcriptional regulation of EMT is not absolute, as the post-transcriptional regulation of hybrid E/M phenotype and EMT associated migration and invasion by Ras has been recently reported [107].

Therapeutic intervention against hybrid E/M cells may evolve as a rational strategy against metastasis and drug resistance. Thapsigargin, a drug which retards lysosomal function and activates an unfolded protein response in the endoplasmic reticulum, acted against hybrid E/M CSCs [CD44 $\left.4^{\mathrm{hi}} / \mathrm{EpCAM}^{\mathrm{lo}} / \mathrm{CD} 24^{\mathrm{hi}}\right]$ in CA1 and LM cells [108]. Simvastatin has been recently reported to target cellular plasticity and retard ovarian cancer metastasis as well as stemness by the downregulation of the Hippo/YAP/RhoA pathway [109]. Immunotherapy may be targeted against the immune checkpoint proteins such as programmed death ligand 1 (PD-L1), which have been frequently found expressed in CTCs of NSCLC and TNBC [3]. Saracatinib (AZD0530), an Src-kinase inhibitor, refurbished E-cad in intermediate $\mathrm{M}$ cells $\left(\mathrm{Ncad}^{\mathrm{hi}} / \mathrm{ZEB} 1^{\mathrm{hi}} / \mathrm{E}-\mathrm{cad}^{\mathrm{lo}}\right)$ which in turn inhibited spheroidogenesis in anoikis-resistant preclinical models of ovarian cancer [44]. The advent of the hybrid metabolic phenotype has warranted the need of targeting both glycolysis and oxidative phosphorylation for combating cancer metabolic plasticity [110].

In future, the cutting edge technologies, such as concurrent measurement of transcriptome and proteome at unicellular level-CITE-seq [111] and REAP-seq [112], intravital correlative microscopy [113], bioinformatics, and mathematical modeling, might be indicative of the underpinning mechanisms of $\mathrm{E} / \mathrm{M}$ plasticity and may provide with better anti-cancer therapeutic interventions.

Author Contributions: Conceptualization and writing, D.S.; writing and figure/tables preparation, P.S. and A.S.; review, editing and suggestion of improvements, A.B. All authors have read and agreed to the published version of the manuscript.

Funding: This research received no external funding.

Acknowledgments: The Indian authors are grateful to Jayanta Chakrabarti, Director, Chittaranjan National Cancer Institute, for providing the infrastructural facilities and the fellowship to P.S. They are also deeply indebted to Department of Science and Technology, Biotechnology, Govt. of West Bengal, India for providing the fellowship to A.S.

Conflicts of Interest: The authors declare no conflict of interests. 
Abbreviations

\begin{tabular}{|c|c|}
\hline ADAM & A disintegrin and metalloproteinases \\
\hline ALDH1 & aldehyde dehydrogenase 1 \\
\hline ANKRD1 & ankyrin repeat domain-containing protein 1 \\
\hline AOX1 & aldehyde oxidase 1 \\
\hline Axl & member of the TYRO3-AXL-MER family of receptor tyrosine kinases \\
\hline Cad & cadherin \\
\hline CAFs & cancer-associated fibroblasts \\
\hline CLDN1 & claudin-1 \\
\hline COL3A1 & collagen Type III $\alpha 1$ Chain \\
\hline CPKV & Pb-Cre+/-;PtenL/L;KrasG12D/+;Vim-GFP \\
\hline CRPC & castration-resistant prostate cancer \\
\hline CSC & cancer stem cell \\
\hline CSF-1 & colony stimulating factor 1 \\
\hline CSF-1R & receptor tyrosine kinase of CSF-1 \\
\hline CTCs & circulating tumour cells \\
\hline CXCL & chemokine ligand \\
\hline CYP & cytochrome P450 \\
\hline DEPTOR & DEP domain-containing mTOR-interacting protein \\
\hline DNMTs & DNA methyl transferases \\
\hline E & epithelial \\
\hline E-cad & epithelial cadherin \\
\hline ECM & extracellular matrix \\
\hline EGFR & epithelial growth factor receptor \\
\hline EMT & epithelial mesenchymal transition \\
\hline EpCAM & epithelial cell adhesion molecule \\
\hline ESCC & esophageal squamous cell carcinoma \\
\hline FGF & fibroblast growth factor \\
\hline FGG & fibrinogen gamma chain \\
\hline FOXC2 & forkhead box protein $\mathrm{C} 2$ \\
\hline GFP & green fluorescence protein \\
\hline GRHL2 & grainyhead like transcription factor 2 \\
\hline GRNs & gene regulatory networks \\
\hline H3К27me3 & tri-methylation at the $27 \mathrm{th}$ lysine residue of the histone $\mathrm{H} 3$ protein \\
\hline H3K4me1 & mono-methylation at the 4 th lysine residue of the histone $\mathrm{H} 3$ protein \\
\hline H3K4me3 & tri-methylation at the 4th lysine residue of the histone $\mathrm{H} 3$ \\
\hline H3К27ac & acetylation at the $27 \mathrm{th}$ lysine residue of the histone $\mathrm{H} 3$ protein \\
\hline $\mathrm{HCC}$ & hepatocellular carcinoma \\
\hline HGF & hepatocyte growth factor \\
\hline HGSOC & high-grade serous ovarian cancer \\
\hline HMLER & human mammary epithelial \\
\hline HNSCC & head and neck squamous cell carcinoma \\
\hline HOTAIR & hOX Transcript Antisense Intergenic RNA \\
\hline IBC & inflammatory breast cancer \\
\hline ITGB4 & integrin- $\beta 4$ \\
\hline Krt & keratin \\
\hline LAMB3 & laminin subunit beta 3 \\
\hline LAMC2 & laminin subunit $\gamma 2$ \\
\hline $\operatorname{lncRNA}$ & long noncoding RNA \\
\hline M & mesenchymal \\
\hline MDCK & Madin-Darby canine kidney cell \\
\hline MET & mesenchymal epithelial transition \\
\hline $\operatorname{miR}$ & microRNA \\
\hline MLNs & metastatic lymph nodes \\
\hline MME & membrane metallo-endopeptidase \\
\hline
\end{tabular}




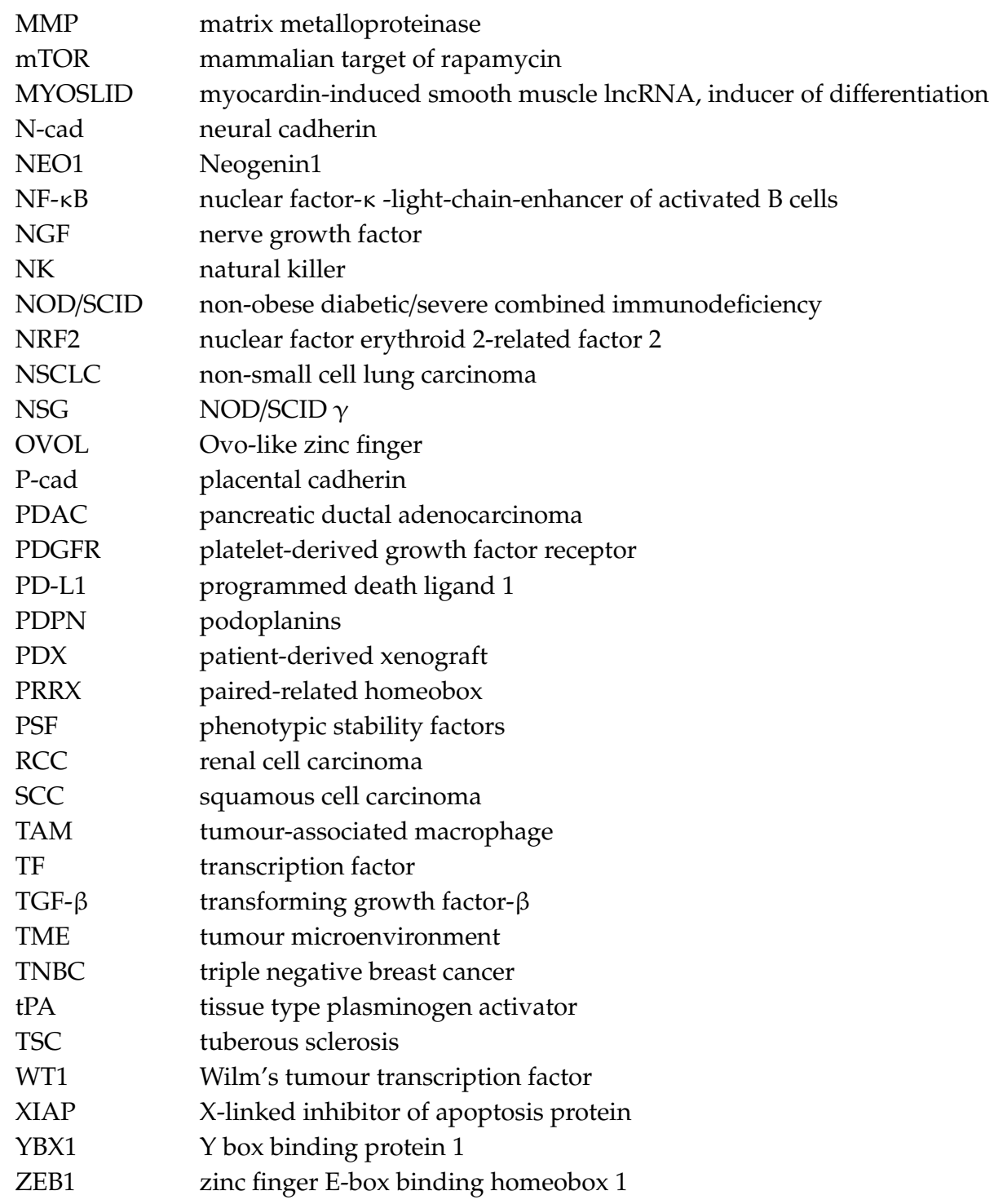

\section{References}

1. Nieto, M. Ángela Epithelial Plasticity: A Common Theme in Embryonic and Cancer Cells. Science 2013, 342, 1234850. [CrossRef] [PubMed]

2. Jie, X.-X.; Zhang, X.-Y.; Xu, C.-J. Epithelial-to-mesenchymal transition, circulating tumor cells and cancer metastasis: Mechanisms and clinical applications. Oncotarget 2017, 8, 81558-81571. [CrossRef] [PubMed]

3. Genna, A.; Vanwynsberghe, A.M.; Villard, A.V.; Pottier, C.; Ancel, J.; Polette, M.; Gilles, C. EMT-Associated Heterogeneity in Circulating Tumor Cells: Sticky Friends on the Road to Metastasis. Cancers 2020, 12, 1632. [CrossRef] [PubMed]

4. Saitoh, M. JB special review-cellular plasticity in epithelial homeostasis and diseases: Involvement of partial EMT in cancer progression. J. Biochem. 2018, 164, 257-264. [CrossRef]

5. Lintz, M.; Muñoz, A.; Reinhart-King, C.A. The Mechanics of Single Cell and Collective Migration of Tumor Cells. J. Biomech. Eng. 2017, 139, 021005-0210059. [CrossRef]

6. Pastushenko, I.; Blanpain, C. EMT Transition States during Tumor Progression and Metastasis. Trends Cell Biol. 2019, 29, 212-226. [CrossRef]

7. Lu, W.; Kang, Y. Epithelial-Mesenchymal Plasticity in Cancer Progression and Metastasis. Dev. Cell 2019, 49, 361-374. [CrossRef]

8. Liao, T.-T.; Yang, M.-H. Hybrid Epithelial/Mesenchymal State in Cancer Metastasis: Clinical Significance and Regulatory Mechanisms. Cells 2020, 9, 623. [CrossRef] 
9. Garg, M. Epithelial plasticity and cancer stem cells: Major mechanisms of cancer pathogenesis and therapy resistance. World J. Stem Cells 2017, 9, 118-126. [CrossRef]

10. Williams, E.D.; Gao, D.; Redfern, A.; Thompson, E.W. Controversies around epithelial-mesenchymal plasticity in cancer metastasis. Nat. Rev. Cancer 2019, 19, 716-732. [CrossRef]

11. Jia, D.; George, J.T.; Tripathi, S.C.; Kundnani, D.L.; Lu, M.; Hanash, S.M.; Onuchic, J.N.; Jolly, M.K.; Levine, H. Testing the gene expression classification of the EMT spectrum. Phys. Biol. 2019, 16, 025002. [CrossRef] [PubMed]

12. Santamaría, P.G.; Mazón, M.J.; Eraso, P.; Portillo, F. UPR: An Upstream Signal to EMT Induction in Cancer. J. Clin. Med. 2019, 8, 624. [CrossRef] [PubMed]

13. Pastushenko, I.; Brisebarre, A.; Sifrim, A.; Fioramonti, M.; Revenco, T.; Boumahdi, S.; Van Keymeulen, A.; Brown, D.; Moers, V.; Lemaire, S.; et al. Identification of the tumour transition states occurring during EMT. Nat. Cell Biol. 2018, 556, 463-468. [CrossRef] [PubMed]

14. Subbalakshmi, A.R.; Sahoo, S.; Biswas, K.; Jolly, M.K. A computational systems biology approach identifies SLUG as a mediator of partial Epithelial-Mesenchymal Transition (EMT). Clin. J. Jpn. Cancer Assoc. 2020, 111, 467-476. [CrossRef]

15. Friedl, P.; Mayor, R. Tuning Collective Cell Migration by Cell-Cell Junction Regulation. Cold Spring Harb. Perspect. Biol. 2017, 9, a029199. [CrossRef] [PubMed]

16. Jolly, M.K.; Somarelli, J.A.; Sheth, M.; Biddle, A.; Tripathi, S.C.; Armstrong, A.J.; Hanash, S.M.; Bapat, S.A.; Rangarajan, A.; Levine, H. Hybrid epithelial/mesenchymal phenotypes promote metastasis and therapy resistance across carcinomas. Pharmacol. Ther. 2019, 194, 161-184. [CrossRef]

17. Kröger, C.; Afeyan, A.; Mraz, J.; Eaton, E.N.; Reinhardt, F.; Khodor, Y.L.; Thiru, P.; Bierie, B.; Ye, X.; Burge, C.B.; et al. Acquisition of a hybrid E/M state is essential for tumorigenicity of basal breast cancer cells. Proc. Natl. Acad. Sci. USA 2019, 116, 7353-7362. [CrossRef]

18. Schliekelman, M.J.; Taguchi, A.; Zhu, J.; Dai, X.; Rodriguez, J.; Celiktas, M.; Zhang, Q.; Chin, A.; Wong, C.-H.; Wang, H.; et al. Molecular Portraits of Epithelial, Mesenchymal, and Hybrid States in Lung Adenocarcinoma and Their Relevance to Survival. Cancer Res. 2015, 75, 1789-1800. [CrossRef]

19. Bocci, F.; Tripathi, S.C.; Mercedes, S.A.V.; George, J.T.; Casabar, J.P.; Wong, P.K.; Hanash, S.M.; Levine, H.; Onuchic, J.N.; Jolly, M.K. NRF2 activates a partial epithelial-mesenchymal transition and is maximally present in a hybrid epithelial/mesenchymal phenotype. Integr. Biol. 2019, 11, 251-263. [CrossRef]

20. Sampson, V.B.; David, J.M.; Puig, I.; Patil, P.U.; De Herreros, A.G.; Thomas, G.V.; Rajasekaran, A.K. Wilms' Tumor Protein Induces an Epithelial-Mesenchymal Hybrid Differentiation State in Clear Cell Renal Cell Carcinoma. PLoS ONE 2014, 9, e102041. [CrossRef]

21. Gopal, S.K.; Greening, D.W.; Mathias, R.A.; Ji, H.; Rai, A.; Chen, M.; Zhu, H.J.; Simpson, R.J. YBX1/YB-1 induces partial EMT and tumourigenicity through secretion of angiogenic factors into the extracellular microenvironment. Oncotarget 2015, 6, 13718-13730. [CrossRef] [PubMed]

22. Juang, Y.-L.; Jeng, Y.-M.; Chen, C.-L.; Lien, H.-C. PRRX2 as a novel TGF- $\beta$-induced factor enhances invasion and migration in mammary epithelial cell and correlates with poor prognosis in breast cancer. Mol. Carcinog. 2016, 55, 2247-2259. [CrossRef] [PubMed]

23. Daugaard, I.; Sanders, K.J.; Idica, A.; Vittayarukskul, K.; Hamdorf, M.; Krog, J.D.; Chow, R.; Jury, D.; Hansen, L.L.; Hager, H.; et al. miR-151a induces partial EMT by regulating E-cadherin in NSCLC cells. Oncogenesis. 2017, 6, e366. [CrossRef] [PubMed]

24. Xiong, H.-G.; Li, H.; Xiao, Y.; Yang, Q.-C.; Yang, L.-L.; Chen, L.; Bu, L.-L.; Zhang, W.-F.; Zhang, J.-L.; Sun, Z.-J. Long noncoding RNA MYOSLID promotes invasion and metastasis by modulating the partial epithelial-mesenchymal transition program in head and neck squamous cell carcinoma. J. Exp. Clin. Cancer Res. 2019, 38, 1-14. [CrossRef] [PubMed]

25. Topel, H.; Bagirsakci, E.; Comez, D.; Bagci, G.; Cakan-Akdogan, G.; Atabey, N. lncRNA HOTAIR overexpression induced downregulation of c-Met signaling promotes hybrid epithelial/mesenchymal phenotype in hepatocellular carcinoma cells. Cell Commun. Signal. 2020, 18, 1-19. [CrossRef] [PubMed]

26. Chaturvedi, V.; Fournier-Level, A.; Cooper, H.M.; Murray, M.J. Loss of Neogenin1 in human colorectal carcinoma cells causes a partial EMT and wound-healing response. Sci. Rep. 2019, 9, 4110. [CrossRef] [PubMed] 
27. Chen, J.; Zhu, H.; Liu, Q.; Ning, D.; Zhang, Z.; Zhang, L.; Mo, J.; Du, P.; Liu, X.; Song, S.; et al. DEPTOR induces a partial epithelial-to-mesenchymal transition and metastasis via autocrine TGF $\beta 1$ signaling and is associated with poor prognosis in hepatocellular carcinoma. J. Exp. Clin. Cancer Res. 2019, 38, 1-14. [CrossRef]

28. Peyre, L.; Zucchini-Pascal, N.; De Sousa, G.; Rahmani, R. Effects of endosulfan on hepatoma cell adhesion: Epithelial-mesenchymal transition and anoikis resistance. Toxicology 2012, 300, 19-30. [CrossRef]

29. Corbet, C.; Bastien, E.; De Jesus, J.P.S.; Dierge, E.; Martherus, R.; Linden, C.V.; Doix, B.; Degavre, C.; Guilbaud, C.; Petit, L.; et al. TGF $\beta 2$-induced formation of lipid droplets supports acidosis-driven EMT and the metastatic spreading of cancer cells. Nat. Commun. 2020, 11,1-15. [CrossRef]

30. Kai, K.; Iwamoto, T.; Zhang, D.; Shen, L.; Takahashi, Y.; Rao, A.; Thompson, A.; Sen, S.; Ueno, N.T. CSF-1/CSF-1R axis is associated with epithelial/mesenchymal hybrid phenotype in epithelial-like inflammatory breast cancer. Sci. Rep. 2018, 8, 9427. [CrossRef]

31. Jones, A.T.; Yang, J.; Narov, K.; Henske, E.P.; Sampson, J.R.; Shen, M.H. Allosteric and ATP-Competitive Inhibitors of mTOR Effectively Suppress Tumor Progression-Associated Epithelial-Mesenchymal Transition in the Kidneys of Tsc2+/- Mice. Neoplasia 2019, 21, 731-739. [CrossRef] [PubMed]

32. Børretzen, A.; Gravdal, K.; Haukaas, S.A.; Beisland, C.; Akslen, L.A.; Halvorsen, O.J. FOXC2 expression and epithelial-mesenchymal phenotypes are associated with castration resistance, metastasis and survival in prostate cancer. J. Pathol. Clin. Res. 2019, 5, 272-286. [CrossRef] [PubMed]

33. Karaosmanoğlu, O.; Banerjee, S.; Sivas, H. Identification of biomarkers associated with partial epithelial to mesenchymal transition in the secretome of slug over-expressing hepatocellular carcinoma cells. Cell. Oncol. 2018, 41, 439-453. [CrossRef] [PubMed]

34. Norgard, R.J.; Stanger, B.Z. Isolation and Identification of EMT Subtypes. In The Epithelial-to Mesenchymal Transition. Methods in Molecular Biology; Campbell, K., Theveneau, E., Eds.; Humana: New York, NY, USA, 2020; p. 2179. [CrossRef]

35. Boareto, M.; Jolly, M.K.; Lu, M.; Onuchic, J.N.; Clementi, C.; Ben-Jacob, E. Jagged-Delta asymmetry in Notch signaling can give rise to a Sender/Receiver hybrid phenotype. Proc. Natl. Acad. Sci. USA 2015, 112, E402-E409. [CrossRef]

36. Jia, D.; Li, X.; Bocci, F.; Tripathi, S.; Deng, Y.; Jolly, M.K.; Onuchic, J.N.; Levine, H. Quantifying Cancer Epithelial-Mesenchymal Plasticity and its Association with Stemness and Immune Response. J. Clin. Med. 2019, 8, 725. [CrossRef]

37. Biswas, K.; Jolly, M.K.; Ghosh, A. Stability and mean residence times for hybrid epithelial/mesenchymal phenotype. Phys. Biol. 2019, 16, 025003. [CrossRef]

38. Jolly, M.K.; Preca, B.-T.; Tripathi, S.C.; Jia, D.; George, J.T.; Hanash, S.M.; Brabletz, T.; Stemmler, M.P.; Maurer, J.; Levine, H. Interconnected feedback loops among ESRP1, HAS2, and CD44 regulate epithelial-mesenchymal plasticity in cancer. APL Bioeng. 2018, 2, 031908. [CrossRef]

39. Bocci, F.; Jolly, M.K.; Tripathi, S.C.; Aguilar, M.; Hanash, S.M.; Levine, H.; Onuchic, J.N. Numb prevents a complete epithelial-mesenchymal transition by modulating Notch signalling. J. R. Soc. Interface 2017, 14, 20170512. [CrossRef]

40. Saitoh, M. Epithelial-mesenchymal transition is regulated at post-transcriptional levels by transforming growth factor- $\beta$ signaling during tumor progression. Cancer Sci. 2015, 106, 481-488. [CrossRef]

41. Horiguchi, K.; Sakamoto, K.M.; Koinuma, D.; Semba, K.; Inoue, A.; Inoue, S.; Fujii, H.; Yamaguchi, A.; Miyazawa, K.; Miyazono, K.; et al. TGF- $\beta$ drives epithelial-mesenchymal transition through $\delta$ EF1-mediated downregulation of ESRP. Oncogene 2012, 31, 3190-3201. [CrossRef]

42. Roca, H.; Hernandez, J.; Weidner, S.; McEachin, R.C.; Fuller, D.; Sud, S.; Schumann, T.; Wilkinson, J.E.; Zaslavsky, A.; Li, H.; et al. Transcription Factors OVOL1 and OVOL2 Induce the Mesenchymal to Epithelial Transition in Human Cancer. PLoS ONE 2013, 8, e76773. [CrossRef] [PubMed]

43. Krebs, A.M.; Mitschke, J.; Losada, M.L.; Schmalhofer, O.; Boerries, M.; Busch, H.; Boettcher, M.; Mougiakakos, D.; Reichardt, W.; Bronsert, P.; et al. The EMT-activator Zeb1 is a key factor for cell plasticity and promotes metastasis in pancreatic cancer. Nat. Cell Biol. 2017, 19, 518-529. [CrossRef] [PubMed]

44. Huang, R.Y.-J.; Wong, M.K.; Tan, T.Z.; Kuay, K.T.; Ng, A.H.C.; Chung, V.Y.; Chu, Y.-S.; Matsumura, N.; Lai, H.-C.; Lee, Y.F.; et al. An EMT spectrum defines an anoikis-resistant and spheroidogenic intermediate mesenchymal state that is sensitive to e-cadherin restoration by a src-kinase inhibitor, saracatinib (AZD0530). Cell Death Dis. 2013, 4, e915. [CrossRef] [PubMed] 
45. Chung, V.Y.; Tan, T.Z.; Ye, J.; Huang, R.-L.; Lai, H.-C.; Kappei, D.; Wollmann, H.; Guccione, E.; Huang, R.Y.-J. The role of GRHL2 and epigenetic remodeling in epithelial-mesenchymal plasticity in ovarian cancer cells. Commun. Biol. 2019, 2, 1-15. [CrossRef] [PubMed]

46. Ruscetti, M.; Dadashian, E.L.; Guo, W.; Quach, B.; Mulholland, D.J.; Park, J.W.; Tran, L.M.; Kobayashi, N.; Bianchi-Frias, D.; Xing, Y.; et al. HDAC inhibition impedes epithelial-mesenchymal plasticity and suppresses metastatic, castration-resistant prostate cancer. Oncogene 2015, 35, 3781-3795. [CrossRef]

47. Dang, T.T.; Esparza, M.A.; Maine, E.A.; Westcott, J.M.; Pearson, G.W. $\Delta$ Np63 $\alpha$ Promotes Breast Cancer Cell Motility through the Selective Activation of Components of the Epithelial-to-Mesenchymal Transition Program. Cancer Res. 2015, 75, 3925-3935. [CrossRef]

48. Bracken, C.P.; Gregory, P.A.; Kolesnikoff, N.; Bert, A.G.; Wang, J.; Shannon, M.F.; Goodall, G.J. A Double-Negative Feedback Loop between ZEB1-SIP1 and the microRNA-200 Family Regulates Epithelial-Mesenchymal Transition. Cancer Res. 2008, 68, 7846-7854. [CrossRef]

49. Tay, Y.; Rinn, J.L.; Pandolfi, P.P. The multilayered complexity of ceRNA crosstalk and competition. Nat. Cell Biol. 2014, 505, 344-352. [CrossRef]

50. Zaidel-Bar, R. Cadherin adhesome at a glance. J. Cell Sci. 2013, 126, 373-378. [CrossRef]

51. Ha, H.-L.; Kwon, T.; Bak, I.S.; Erikson, R.L.; Kim, B.Y.; Yu, D.-Y. IGF-II induced by hepatitis B virus X protein regulates EMT via SUMO mediated loss of E-cadherin in mice. Oncotarget 2016, 7, 56944-56957. [CrossRef]

52. Brabletz, T. EMT and MET in Metastasis: Where Are the Cancer Stem Cells? Cancer Cell 2012, 22, 699-701. [CrossRef] [PubMed]

53. Santamaría, P.G.; Moreno-Bueno, G.; Cano, A. Contribution of Epithelial Plasticity to Therapy Resistance. J. Clin. Med. 2019, 8, 676. [CrossRef] [PubMed]

54. Wolf, K.; Wu, Y.I.; Liu, Y.; Geiger, J.; Tam, E.; Overall, C.M.; Stack, M.S.; Friedl, P. Multi-step pericellular proteolysis controls the transition from individual to collective cancer cell invasion. Nat. Cell Biol. 2007, 9, 893-904. [CrossRef] [PubMed]

55. Labernadie, A.; Kato, T.; Brugués, A.; Serra-Picamal, X.; Derzsi, S.; Arwert, E.; Weston, A.; González-Tarragó, V.; Elosegui-Artola, A.; Albertazzi, L.; et al. A mechanically active heterotypic E-cadherin/N-cadherin adhesion enables fibroblasts to drive cancer cell invasion. Nat. Cell Biol. 2017, 19, 224-237. [CrossRef] [PubMed]

56. Nieto, M.A.; Huang, R.Y.-J.; Jackson, R.A.; Thiery, J.P. EMT: 2016. Cell 2016, 166, 21-45. [CrossRef] [PubMed]

57. Saxena, K.; Jolly, M.K.; Balamurugan, K. Hypoxia, partial EMT and collective migration: Emerging culprits in metastasis. Transl. Oncol. 2020, 13, 100845. [CrossRef] [PubMed]

58. Latil, M.; Nassar, D.; Beck, B.; Boumahdi, S.; Wang, L.L.; Brisebarre, A.; Dubois, C.; Nkusi, E.; Lenglez, S.; Checinska, A.; et al. Cell-Type-Specific Chromatin States Differentially Prime Squamous Cell Carcinoma Tumor-Initiating Cells for Epithelial to Mesenchymal Transition. Cell Stem Cell 2017, 20, 191-204.e5. [CrossRef]

59. Jolly, M.K.; Tripathi, S.C.; Jia, D.; Mooney, S.M. Stability of the hybrid epithelial / mesenchymal phenotype. Oncotarget 2016, 7, 27067-27084. [CrossRef]

60. Jolly, M.K.; Jia, D.; Boareto, M.; Mani, S.A.; Pienta, K.J.; Ben-Jacob, E.; Levine, H. Coupling the modules of EMT and stemness: A tunable 'stemness window' model. Oncotarget 2015, 6, 25161-25174. [CrossRef]

61. Natsuizaka, M.; Whelan, K.A.; Kagawa, S.; Tanaka, K.; Giroux, V.; Chandramouleeswaran, P.M.; Long, A.; Sahu, V.; Darling, D.S.; Veronique, G.; et al. Interplay between Notch1 and Notch3 promotes EMT and tumor initiation in squamous cell carcinoma. Nat. Commun. 2017, 8, 1-16. [CrossRef]

62. He, P.; Qiu, K.; Jia, Y. Modeling of mesenchymal hybrid epithelial state and phenotypic transitions in EMT and MET processes of cancer cells. Sci. Rep. 2018, 8, 14323. [CrossRef] [PubMed]

63. Chakraborty, P.; George, J.T.; Tripathi, S.; Levine, H.; Jolly, M.K. Comparative Study of Transcriptomics-Based Scoring Metrics for the Epithelial-Hybrid-Mesenchymal Spectrum. Front. Bioeng. Biotechnol. 2020, 8, 220. [CrossRef] [PubMed]

64. Jolly, M.K.; Boareto, M.; Huang, B.; Jia, D.; Lu, M.; Levine, H.; Ben-jacob, E.; Cells, C.S.; Systems, C. Implications of the hybrid epithelial / mesenchymal phenotype in metastasis. Front. Oncol. 2015, 5, 155. [CrossRef] [PubMed]

65. Robertson, F.; Chu, K.; Fernandez, S.V.; Mu, Z.; Zhang, X.; Liu, H.; Boley, K.M.; Alpaugh, R.K.; Ye, Z.; Wright, M.C.; et al. Genomic Profiling of Pre-Clinical Models of Inflammatory Breast Cancer Identifies a Signature of Epithelial Plasticity and Suppression of TGF $\beta$ Signaling. J. Clin. Exp. Pathol. 2012, 2, 119. [CrossRef] 
66. Grosse-Wilde, A.; D’Hérouël, A.F.; McIntosh, E.; Ertaylan, G.; Skupin, A.; Kuestner, R.E.; Del Sol, A.; Walters, K.-A.; Huang, S. Stemness of the hybrid Epithelial/Mesenchymal State in Breast Cancer and Its Association with Poor Survival. PLoS ONE 2015, 10, e0126522. [CrossRef]

67. Zhang, J.; Tian, X.-J.; Zhang, H.; Teng, Y.; Li, R.; Bai, F.; Elankumaran, S.; Xing, J. TGF- -induced epithelial-to-mesenchymal transition proceeds through stepwise activation of multiple feedback loops. Sci. Signal. 2014, 7, ra91. [CrossRef]

68. Fustaino, V.; Presutti, D.; Colombo, T.; Cardinali, B.; Papoff, G.; Brandi, R.; Bertolazzi, P.; Felici, G.; Ruberti, G. Characterization of epithelial-mesenchymal transition intermediate/hybrid phenotypes associated to resistance to EGFR inhibitors in non-small cell lung cancer cell lines. Oncotarget 2017, 8, 103340-103363. [CrossRef]

69. George, J.T.; Jolly, M.K.; Xu, S.; Somarelli, J.A.; Levine, H. Survival Outcomes in Cancer Patients Predicted by a Partial EMT Gene Expression Scoring Metric. Cancer Res. 2017, 77, 6415-6428. [CrossRef]

70. Harner-Foreman, N.; Vadakekolathu, J.; Laversin, S.A.; Mathieu, M.G.; Reeder, S.; Pockley, A.G.; Rees, R.C.; Boocock, D.J. A novel spontaneous model of epithelial-mesenchymal transition (EMT) using a primary prostate cancer derived cell line demonstrating distinct stem-like characteristics. Sci. Rep. 2017, 7, 40633. [CrossRef]

71. Bronsert, P.; Enderle-Ammour, K.; Bader, M.; Timme, S.; Kuehs, M.; Csanadi, A.; Kayser, G.; Kohler, I.; Bausch, D.; Hoeppner, J.; et al. Cancer cell invasion and EMT marker expression: A three-dimensional study of the human cancer-host interface. J. Pathol. 2014, 234, 410-422. [CrossRef]

72. Skoda, J.; Neradil, J.; Zambo, I.S.; Nunukova, A.; Veselska, R. Serial Xenotransplantation in NSG Mice Promotes a Hybrid Epithelial / Mesenchymal Gene Expression. Cancers 2020, 12, 196. [CrossRef] [PubMed]

73. Mizukoshi, K.; Okazawa, Y.; Haeno, H.; Koyama, Y.; Sulidan, K.; Komiyama, H.; Saeki, H.; Ohtsuji, N.; Ito, Y.; Kojima, Y.; et al. Metastatic seeding of human colon cancer cell clusters expressing the hybrid epithelial/mesenchymal state. Int. J. Cancer 2020, 146, 2547-2562. [CrossRef] [PubMed]

74. Strauss, R.; Li, Z.Y.; Liu, Y.; Beyer, I.; Persson, J.; Sova, P.; Möller, T.; Pesonen, S.; Hemminki, A.; Hamerlik, P.; et al. Analysis of epithelial and mesenchymal markers in ovarian cancer reveals phenotypic heterogeneity and plasticity. PLOS ONE 2011, 6, 1-20. [CrossRef]

75. Li, C.; Heidt, D.G.; Dalerba, P.; Burant, C.F.; Zhang, L.; Adsay, V.; Wicha, M.; Clarke, M.F.; Simeone, D.M.; Lepelletier, Y.; et al. Identification of Pancreatic Cancer Stem Cells. Cancer Res. 2007, 67, 1030-1037. [CrossRef] [PubMed]

76. Mercurio, A. Faculty Opinions recommendation of EMT subtype influences epithelial plasticity and mode of cell migration. Fac. Opin. 2019, 45, 681-695. [CrossRef]

77. Ruscetti, M.; Quach, B.; Dadashian, E.L.; Mulholland, D.J.; Wu, H. Tracking and Functional Characterization of Epithelial-Mesenchymal Transition and Mesenchymal Tumor Cells during Prostate Cancer Metastasis. Cancer Res. 2015, 75, 2749-2759. [CrossRef]

78. Putzke, A.P.; Ventura, A.P.; Bailey, A.M.; Akture, C.; Opoku-Ansah, J.; Çeliktaş, M.; Hwang, M.S.; Darling, D.S.; Coleman, I.M.; Nelson, P.S.; et al. Metastatic Progression of Prostate Cancer and E-Cadherin. Am. J. Pathol. 2011, 179, 400-410. [CrossRef]

79. Goossens, N.; Hoshida, Y.; Aguirre-Ghiso, J.A. Origin and interpretation of cancer transcriptome profiling: The essential role of the stroma in determining prognosis and drug resistance. EMBO Mol. Med. 2015, 7, 1385-1387. [CrossRef]

80. Puram, S.V.; Tirosh, I.; Parikh, A.S.; Patel, A.P.; Yizhak, K.; Gillespie, S.; Rodman, C.; Luo, C.L.; Mroz, E.A.; Emerick, K.S.; et al. Single-Cell Transcriptomic Analysis of Primary and Metastatic Tumor Ecosystems in Head and Neck Cancer. Cell 2017, 171, 1611-1624.e24. [CrossRef]

81. Grigore, A.D.; Jolly, M.K.; Jia, D.; Farach-Carson, M.; Levine, H. Tumor Budding: The Name is EMT. Partial EMT. J. Clin. Med. 2016, 5, 51. [CrossRef]

82. Kolijn, K.; Verhoef, E.I.; Van Leenders, G.J. Morphological and immunohistochemical identification of epithelial-to-mesenchymal transition in clinical prostate cancer. Oncotarget 2015, 6, 24488-24498. [CrossRef] [PubMed]

83. Lecharpentier, A.; Vielh, P.; Perez-Moreno, P.; Planchard, D.; Soria, J.-C.; Farace, F. Detection of circulating tumour cells with a hybrid (epithelial/mesenchymal) phenotype in patients with metastatic non-small cell lung cancer. Br. J. Cancer 2011, 105, 1338-1341. [CrossRef] [PubMed] 
84. Blassl, C.; Kuhlmann, J.D.; Webers, A.; Wimberger, P.; Fehm, T.; Neubauer, H. Gene expression profiling of single circulating tumor cells in ovarian cancer - Establishment of a multi-marker gene panel. Mol. Oncol. 2016, 10, 1030-1042. [CrossRef] [PubMed]

85. Armstrong, A.J.; Marengo, M.S.; Oltean, S.; Kemeny, G.; Bitting, R.L.; Turnbull, J.D.; Herold, C.I.; Marcom, P.K.; George, D.J.; Garcia-Blanco, M.A. Circulating Tumor Cells from Patients with Advanced Prostate and Breast Cancer Display Both Epithelial and Mesenchymal Markers. Mol. Cancer Res. 2011, 9, 997-1007. [CrossRef]

86. Wen, J.; Luo, K.-J.; Liu, Q.-W.; Wang, G.; Zhang, M.-F.; Xie, X.-Y.; Yang, H.; Fu, J.-H.; Shui-Shen, Z. The epithelial-mesenchymal transition phenotype of metastatic lymph nodes impacts the prognosis of esophageal squamous cell carcinoma patients. Oncotarget 2016, 7, 37581-37588. [CrossRef]

87. Strati, A.; Nikolaou, M.; Georgoulias, V.; Lianidou, E.S. Prognostic Significance of TWIST1, CD24, CD44, and ALDH1 Transcript Quantification in EpCAM-Positive Circulating Tumor Cells from Early Stage Breast Cancer Patients. Cells 2019, 8, 652. [CrossRef]

88. Yamashita, N.; Tokunaga, E.; Iimori, M.; Inoue, Y.; Tanaka, K.; Kitao, H.; Saeki, H.; Oki, E.; Maehara, Y. Epithelial Paradox: Clinical Significance of Coexpression of E-cadherin and Vimentin with Regard to Invasion and Metastasis of Breast Cancer. Clin. Breast Cancer 2018, 18, e1003-e1009. [CrossRef]

89. Meyer, S.N.; Galván, J.A.; Zahnd, S.; Sokol, L.; Dawson, H.; Lugli, A.; Zlobec, I. Co-expression of cytokeratin and vimentin in colorectal cancer highlights a subset of tumor buds and an atypical cancer-associated stroma. Hum. Pathol. 2019, 87, 18-27. [CrossRef]

90. Gonzalez, V.D.; Samusik, N.; Chen, T.J.; Savig, E.S.; Aghaeepour, N.; Quigley, D.A.; Huang, Y.-W.; Giangarrà, V.; Borowsky, A.D.; Hubbard, N.E.; et al. Commonly Occurring Cell Subsets in High-Grade Serous Ovarian Tumors Identified by Single-Cell Mass Cytometry. Cell Rep. 2018, 22, 1875-1888. [CrossRef]

91. Zacharias, M.; Brcic, L.; Eidenhammer, S.; Popper, H.H. Bulk tumour cell migration in lung carcinomas might be more common than epithelial-mesenchymal transition and be differently regulated. BMC Cancer 2018, 18, 717. [CrossRef]

92. Andriani, F.; Bertolini, G.; Facchinetti, F.; Baldoli, E.; Moro, M.; Casalini, P.; Caserini, R.; Milione, M.; Leone, G.; Pelosi, G.; et al. Conversion to stem-cell state in response to microenvironmental cues is regulated by balance between epithelial and mesenchymal features in lung cancer cells. Mol. Oncol. 2015, 10, 253-271. [CrossRef] [PubMed]

93. Reese, J.B.; Bober, S.L.; Daly, M.B.; Program, C.; Chase, F.; Sciences, B.; Care, P.; Chase, F.; Behavior, S.; Neoplasms, B. Single-cell transcriptomic analysis of primary and metastatic tumor ecosystems in head and neck cancer. Cell 2018, 123, 4757-4763.

94. Saha, M.; Kumar, S.; Bukhari, S.; Balaji, S.A.; Kumar, P.; Hindupur, S.K.; Rangarajan, A. AMPK-Akt Double-Negative Feedback Loop in Breast Cancer Cells Regulates Their Adaptation to Matrix Deprivation. Cancer Res. 2018, 78, 1497-1510. [CrossRef] [PubMed]

95. Baccelli, I.; Schneeweiss, A.; Riethdorf, S.; Stenzinger, A.; Schillert, A.; Vogel, V.; Klein, C.; Saini, M.; Bäuerle, T.; Wallwiener, M.; et al. Identification of a population of blood circulating tumor cells from breast cancer patients that initiates metastasis in a xenograft assay. Nat. Biotechnol. 2013, 31, 539-544. [CrossRef] [PubMed]

96. Jolly, M.K.; Boareto, M.; Debeb, B.G.; Aceto, N.; Farach-Carson, M.C.; Woodward, W.A.; Levine, H. Inflammatory breast cancer: A model for investigating cluster-based dissemination. NPJ Breast Cancer 2017, 3, 1-8. [CrossRef]

97. Klymenko, Y.; Kim, O.; Stack, M.S. Complex Determinants of Epithelial: Mesenchymal Phenotypic Plasticity in Ovarian Cancer. Cancers 2017, 9, 104. [CrossRef]

98. Celià-Terrassa, T.; Meca-Cortés, Ó.; Mateo, F.; De Paz, A.M.; Rubio, N.; Arnal-Estapé, A.; Ell, B.J.; Bermudo, R.; Díaz, A.; Guerra-Rebollo, M.; et al. Epithelial-mesenchymal transition can suppress major attributes of human epithelial tumor-initiating cells. J. Clin. Investig. 2012, 122, 1849-1868. [CrossRef]

99. Gugnoni, M.; Sancisi, V.; Gandolfi, G.; Manzotti, G.; Ragazzi, M.; Giordano, D.; Tamagnini, I.; Tigano, M.; Frasoldati, A.; Piana, S.; et al. Cadherin-6 promotes EMT and cancer metastasis by restraining autophagy. Oncogene 2016, 36, 667-677. [CrossRef]

100. Quan, Q.; Wang, X.; Lu, C.; Ma, W.; Wang, Y.; Xia, G.; Wang, C.; Yang, G. Cancer stem-like cells with hybrid epithelial/mesenchymal phenotype leading the collective invasion. Cancer Sci. 2020, 111, 467-476. [CrossRef]

101. Al-Hajj, M.; Wicha, M.S.; Benito-Hernandez, A.; Morrison, S.J.; Clarke, M.F. Prospective identification of tumorigenic breast cancer cells. Proc. Natl. Acad. Sci. USA 2003, 100, 3983-3988. [CrossRef] 
102. Bierie, B.; Pierce, S.E.; Kroeger, C.; Stover, D.G.; Pattabiraman, D.R.; Thiru, P.; Donaher, J.L.; Reinhardt, F.; Chaffer, C.L.; Keckesova, Z.; et al. Integrin- $\beta 4$ identifies cancer stem cell-enriched populations of partially mesenchymal carcinoma cells. Proc. Natl. Acad. Sci. USA 2017, 114, E2337-E2346. [CrossRef] [PubMed]

103. Colacino, J.A.; Azizi, E.; Brooks, M.D.; Harouaka, R.; Fouladdel, S.; McDermott, S.P.; Lee, M.; Hill, D.; Madden, J.; Boerner, J.; et al. Heterogeneity of Human Breast Stem and Progenitor Cells as Revealed by Transcriptional Profiling. Stem Cell Rep. 2018, 10, 1596-1609. [CrossRef] [PubMed]

104. Mooney, S.M.; Talebian, V.; Jolly, M.K.; Jia, D.; Gromala, M.; Levine, H.; McConkey, B.J. The GRHL2/ZEB Feedback Loop-A Key Axis in the Regulation of EMT in Breast Cancer. J. Cell. Biochem. 2017, 118, 2559-2570. [CrossRef] [PubMed]

105. Gao, Y.; Zhang, Z.; Li, K.; Gong, L.; Yang, Q.; Huang, X.; Hong, C.; Ding, M.; Yang, H. Linc-DYNC2H1-4 promotes EMT and CSC phenotypes by acting as a sponge of miR-145 in pancreatic cancer cells. Cell Death Dis. 2017, 8, e2924. [CrossRef] [PubMed]

106. Kim, A.-Y.; Kwak, J.-H.; Je, N.K.; Lee, Y.-H.; Jung, Y.-S. Epithelial-mesenchymal Transition is Associated with Acquired Resistance to 5-Fluorocuracil in HT-29 Colon Cancer Cells. Toxicol. Res. 2015, 31, 151-156. [CrossRef] [PubMed]

107. Bisogno, L.S.; Friedersdorf, M.B.; Keene, J.D. Ras Post-transcriptionally Enhances a Pre-malignantly Primed EMT to Promote Invasion. iScience 2018, 4, 97-108. [CrossRef]

108. Biddle, A.; Gammon, L.; Liang, X.; Costea, D.E.; MacKenzie, I.C. Phenotypic Plasticity Determines Cancer Stem Cell Therapeutic Resistance in Oral Squamous Cell Carcinoma. EBioMedicine 2016, 4, 138-145. [CrossRef]

109. Kato, S.; Liberona, M.F.; Cerda-Infante, J.; Sánchez, M.; Henriquez, J.F.; Bizama, C.; Bravo, M.L.; González, P.; Gejman, R.; Brañes, J.; et al. Simvastatin interferes with cancer 'stem-cell' plasticity reducing metastasis in ovarian cancer. Endocrine-Relat. Cancer 2018, 25, 821-836. [CrossRef]

110. Jia, D.; Lu, M.; Jung, K.H.; Park, J.H.; Yu, L.; Onuchic, J.N.; Kaipparettu, B.A.; Levine, H. Elucidating cancer metabolic plasticity by coupling gene regulation with metabolic pathways. Proc. Natl. Acad. Sci. USA 2019, 116, 3909-3918. [CrossRef]

111. Stoeckius, M.; Hafemeister, C.; Stephenson, W.; Houck-Loomis, B.; Chattopadhyay, P.K.; Swerdlow, H.; Satija, R.; Smibert, P. Simultaneous epitope and transcriptome measurement in single cells. Nat. Methods 2017, 14, 865-868. [CrossRef]

112. Peterson, V.M.; Zhang, K.X.; Kumar, N.; Wong, J.; Li, L.; Wilson, D.C.; Moore, R.; McClanahan, T.K.; Sadekova, S.; Klappenbach, J.A. Multiplexed quantification of proteins and transcripts in single cells. Nat. Biotechnol. 2017, 35, 936-939. [CrossRef] [PubMed]

113. Karreman, M.A.; Hyenne, V.; Schwab, Y.; Goetz, J.G. Intravital Correlative Microscopy: Imaging Life at the Nanoscale. Trends Cell Biol. 2016, 26, 848-863. [CrossRef] [PubMed]

Publisher's Note: MDPI stays neutral with regard to jurisdictional claims in published maps and institutional affiliations.

(C) 2020 by the authors. Licensee MDPI, Basel, Switzerland. This article is an open access article distributed under the terms and conditions of the Creative Commons Attribution (CC BY) license (http://creativecommons.org/licenses/by/4.0/). 